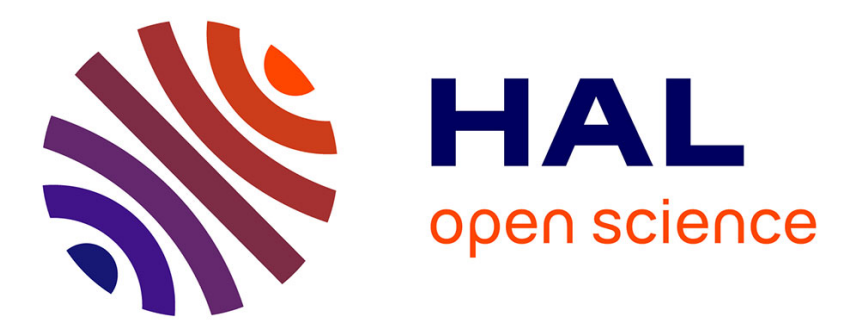

\title{
Primary production in coastal lagoons supported by groundwater discharge and porewater fluxes inferred from nitrogen and carbon isotope signatures
}

Aladin Andrisoa, Thomas Stieglitz, Valenti Rodellas, Patrick Raimbault

\section{To cite this version:}

Aladin Andrisoa, Thomas Stieglitz, Valenti Rodellas, Patrick Raimbault. Primary production in coastal lagoons supported by groundwater discharge and porewater fluxes inferred from nitrogen and carbon isotope signatures. Marine Chemistry, 2019, 210, pp.48-60. 10.1016/j.marchem.2019.03.003 . hal-02069089

\section{HAL Id: hal-02069089 \\ https://hal.science/hal-02069089}

Submitted on 20 Mar 2019

HAL is a multi-disciplinary open access archive for the deposit and dissemination of scientific research documents, whether they are published or not. The documents may come from teaching and research institutions in France or abroad, or from public or private research centers.
L'archive ouverte pluridisciplinaire HAL, est destinée au dépôt et à la diffusion de documents scientifiques de niveau recherche, publiés ou non, émanant des établissements d'enseignement et de recherche français ou étrangers, des laboratoires publics ou privés. 


\section{Primary production in coastal lagoons supported by groundwater discharge and porewater fluxes inferred from nitrogen and carbon isotope signatures}

Aladin Andrisoa ${ }^{1 *}$, Thomas C. Stieglitz ${ }^{1,2}$, Valentí Rodellas ${ }^{1}$, Patrick Raimbault ${ }^{3}$

${ }^{1}$ Aix-Marseille Université, CNRS, IRD, INRA, Coll France, CEREGE, 13545 Aixen-Provence, France

${ }^{2}$ Centre for Tropical Water and Aquatic Ecosystem Research, James Cook University, Townsville, Queensland 4811, Australia

${ }^{3}$ Aix Marseille Université, CNRS/INSU, Université de Toulon, IRD, Mediterranean Institute of Oceanography (MIO) UM 110, 13288, Marseille, France

*Corresponding Author: Aladin Andrisoa (andrisoa@cerege.fr)

Thomas C. Stieglitz: stieglitz@cerege.fr

Valentí Rodellas: rodellas@cerege.fr

Patrick Raimbault: patrick.raimbault@mio.osupytheas.fr 


\begin{abstract}
The role of groundwater and porewater fluxes as a source of nutrients to coastal ecosystems and their ecological implications are increasingly being recognized. In this study, the role of groundwater discharge and porewater fluxes in supporting primary production of coastal lagoons was evaluated by stable nitrogen and carbon isotope signature tracing of the transfer of nitrogen and carbon to primary producers. We determined the isotope signatures in macrophytes and phytoplankton (via particulate organic matter) and in the potential sources of inorganic nitrogen and carbon in two coastal lagoons on the French Mediterranean coastline. The $\delta^{15} \mathrm{~N}$ of both macrophytes and phytoplankton reflect predominantly the nitrogen isotopic signatures of the karstic groundwater and porewater sources, indicating that they must have sourced the majority of their nitrogen from these sources, with punctual contributions from sewage input characterised by a significantly different isotopic signature. The $\delta^{13} \mathrm{C}$ signature of primary producers also shows the contribution of karstic groundwater discharge and porewater exchange as significant sources of dissolved inorganic carbon to primary production. This study links physical (nutrient delivery) and ecological (nutrient uptake) processes associated with primary production, thereby providing direct evidence for the ecological role groundwater discharge and porewater fluxes can play in coastal ecosystems.
\end{abstract}

Keywords: coastal lagoons, groundwater discharge, porewater fluxes, primary production, nitrogen isotopes, carbon isotopes 


\section{Introduction}

Nitrogen and carbon inputs from terrestrial and sedimentary sources are key drivers of primary production in coastal ecosystems (Zheng 2009; Chappuis Eglantine et al. 2017). The contribution of surface water fluxes (rivers, streams, runoff...) to coastal nitrogen and carbon budgets have been extensively documented (Middelburg and Nieuwenhuize 2001; Brunet et al. 2005). In recent years, it has also been recognised that dissolved inorganic nitrogen and carbon are significantly supplied by both groundwater discharge and porewater fluxes (sometimes referred as recirculation processes) (Burnett et al. 2003; Slomp and Van Cappellen 2004; Kroeger et al. 2007; Deborde et al. 2008; Knee et al. 2010; Santos et al. 2012a; Atkins et al. 2013; Anschutz et al. 2016). Inputs of dissolved inorganic nitrogen and carbon associated with groundwater discharge and porewater fluxes can sometimes rival those fluxes supplied by surface runoff (Dorsett et al. 2011; Cyronak et al. 2013; TovarSánchez et al. 2014). For the purpose of this study, we use the term karstic groundwater for low-salinity groundwater driven by the terrestrial hydraulic gradient and porewater fluxes to refer to the total efflux of saline water across the sediment-water interface (Burnett et al. 2003; Santos et al. 2012a). Unlike other studies that distinguish benthic fluxes into Submarine Groundwater Discharge or porewater exchange depending on the spatial scale of the recirculation process (Moore 2010; Santos et al. 2012a, 2014), here we use the term porewater fluxes to include all benthic fluxes, regardless of their spatial scale.

A considerable and growing body of work suggests important ecological implications linked to groundwater and porewater fluxes in coastal systems, e.g. eutrophication, algal blooms, hypoxia events (e.g. Valiela et al. 1992, Rodellas et al. 2014; Wang et al. 2016). Most of these studies are based on indirect evidence, i.e. by measuring nutrient fluxes to coastal sites and subsequent inference that these nutrients are taken up by primary producers. Indeed, to date, only a comparatively small number of studies have directly addressed the transfer of dissolved nitrogen and carbon originated from groundwater discharge and porewater fluxes into primary producers (Herrera-Silveira 1998; McClelland and Valiela 1998; Valiela and Costa 1988; 
Hwang et al. 2005). This study aims at demonstrating the direct impact on lagoon ecological processes by documenting the transfer of groundwater and porewater derived nutrients into primary producers, thereby linking physical (nutrient delivery) and ecological (nutrient uptake) processes.

Inputs of nitrogen (mainly $\mathrm{NO}_{3}{ }^{-}$and $\mathrm{NH}_{4}{ }^{+}$) to the coastal zone supplied by groundwater and porewater fluxes can be derived from natural (e.g. vegetation, rocks, microorganisms cycling) or anthropogenic sources (e.g. fertilizers, sewage, mining waste) (Valiela et al. 1992; Slomp and Van Cappellen 2004; Cole et al. 2006). Additional sources of dissolved inorganic nitrogen to coastal environments are the disposal of wastewater and atmospheric deposition directly to the aquatic system (Valiela et al. 1992; Cole et al. 2005). In the case of carbon, aside from groundwater and porewaterdriven inputs, dissolved inorganic carbon (mainly dissolved $\mathrm{CO}_{2}$ and $\mathrm{HCO}_{3}{ }^{-}$) originates also from atmospheric $\mathrm{CO}_{2}$, mineralisation of organic matter in surface waters, respiration and rock weathering (Brunet et al. 2005; Hansen et al. 2006). In order to fully evaluate nutrient budgets of a coastal water body, a distinction of 'new' external and 'old' regenerated or recycled nutrients is required. Nitrogen and carbon inputs supplied by external sources (e.g. karstic groundwater, atmospheric deposition or direct wastewater discharge) represent inputs of new nutrients to the lagoonal system, but this is not necessarily the case for porewater fluxes. Net nitrogen and carbon fluxes driven by porewater inputs may originate from the remineralization of organic matter or the recycling of inorganic nutrients within the sediment (Weinstein et al. 2011; Sadat-Noori et al. 2016). Thus, whilst referred to as porewaterdriven nitrogen and carbon inputs, they could be originally supplied by other sources. In other words, groundwater and (in particular) porewater can represent any combination of these 'original' source terms, and it may perhaps be more appropriate to use the term 'pathway' rather than 'source'. This is particularly the case for porewater derived inputs. However, we will use the term 'source' to refer to groundwater and porewater inputs, as commonly done in coastal groundwater studies. Whilst the application of stable isotopes of species of interest (here N \& C) can help with these investigations, they alone do not allow for the full distinction of new versus old (regenerated) 
sources. We suggest that this limitation is common to almost all studies of chemical fluxes associated with porewater exchange, and that this issue will require further investigations if a full nutrient (or solute) budget was to be obtained.

In order to establish the sources that supply nitrogen and carbon for the growth of primary producers, natural abundance ratios of stable nitrogen and carbon isotopes $\left(\delta^{15} \mathrm{~N}\right.$ and $\left.\delta^{13} \mathrm{C}\right)$ are widely used (Zieman et al. 1984; Lassauque et al. 2010). Primary producers integrate the isotopic signature of their nitrogen and carbon sources over their lifetime and thus provide an insight into the potential sources at that time scale (e.g. Derse et al. 2007; Santiago et al. 2017). Isotope fractionation during nutrient uptake may induce variations in the $\delta^{15} \mathrm{~N}$ and $\delta^{13} \mathrm{C}$ in the primary producers and needs to be taken into account for an appropriate evaluation (Hemminga \& Mateo, 1996; Lepoint et al., 2004).

Typical ranges of $\delta^{15} \mathrm{~N}$ in source terms are +2 to $+5 \%$ o for nitrogen in soil, -3 to $+3 \%$ for fertilizers, +2 to $+8 \%$ for groundwater from natural soils and +10 to $+20 \%$ o for sewage effluent (Kendall et al. 2007; Kendall 2015). Provided that different sources supplying an ecosystem have distinguishable signatures, their relative contributions can be identified by comparing the $\delta^{15} \mathrm{~N}$ signatures in primary producers with those of the sources (Derse et al. 2007; Benson et al. 2008).

Similarly, carbon stable isotopes incorporated in the primary producer's biomass can be used to trace the source of inorganic carbon and provide insight into the carbon cycling processes and the environmental conditions during growth (Vizzini et al. 2005; Inglett and Reddy 2006). The isotopic signature of dissolved inorganic carbon $\left(\delta^{13} \mathrm{C}\right.$-DIC $)$ available for photosynthesis chiefly determines the isotopic signatures in primary producers (Boschker et al., 2005; Hemminga \& Mateo, 1996). In seawater, $\delta^{13} \mathrm{C}$-DIC is around 0\%o (Hemminga and Mateo 1996; Raven et al. 2002), $\delta^{13} \mathrm{C}$ DIC ranges between -11 and $-8 \%$ in groundwater (Atekwana and Krishnamurthy 1998), and is around $-11 \%$ in sewage effluent (Barros et al. 2010). 
The objective of this study is to assess the role of groundwater discharge and porewater fluxes in supporting primary production of groundwater-fed coastal lagoons. We studied the transfer of dissolved nitrogen and carbon originated from groundwater and advective porewater fluxes to macrophytes and phytoplankton in two lagoons on the French Mediterranean coastline (Figure 1). The smaller La Palme lagoon receives relatively large amounts of groundwater, significantly diluting lagoon salinity, whereas the larger Salses-Leucate lagoon experiences only partial fresh groundwater exposure (Stieglitz et al. 2013).

\section{Materials and Methods}

\subsection{Study area}

The study region experiences rainfall during fall and spring (total up to $500 \mathrm{~mm}$ per year) with little rain during summer (Carlier et al., 2007). Small streams connected to the coastal lagoons in the region are dry all year round except during strong rainfall events. Surface water input is thus a negligible source of nutrients to those lagoons.

La Palme lagoon (Figure 1a) is a small and shallow oligotrophic lagoon (surface area ca. 500 ha; mean depth $0.5 \mathrm{~m}$ ) and one of the rare remaining pristine systems in the region (Derolez et al. 2015). It has a relatively small catchment area $\left(\sim 65 \mathrm{~km}^{2}\right)$ that is little affected by human activities (Carlier et al. 2007). La Palme lagoon is seasonally connected with the Mediterranean Sea via a small opening, which is usually closed during summer and periodically opens between fall and spring. Throughout the year, the lagoon receives freshwater from a limestone aquifer (3-25 $210^{3} \mathrm{~m}^{3} \mathrm{~d}^{-1}$; Rodellas et al. 2018), mainly through a karstic spring ( $\sim 50 \%)$, connected to the lagoon via a small, short stream in the northwestern part of the lagoon (Wilke and Boutière 2000). A sewage treatment plant intermittently discharges treated wastewater into the north part of the lagoon from La Palme village (1700 inhabitants) with a mean water flow of $2.6 \times 10^{2} \mathrm{~m}^{3} \mathrm{~d}^{-1}$ (PNRNM 2016). Strong north-westerly winds, regularly exceeding $20 \mathrm{~m} \mathrm{~s}^{-1}$, play an important role in the 
hydrodynamics of the lagoons. They regulate the lagoon connection with the open sea and drive porewater fluxes (Stieglitz et al. 2013; Cook et al. 2018).

Salses-Leucate lagoon is a relatively large lagoon (5600 ha) with a mean and maximum depth of $1.5 \mathrm{~m}$ and $3.5 \mathrm{~m}$, respectively. The catchment area is relatively large $\left(\sim 160 \mathrm{~km}^{2}\right)$ with high agriculture activities $(32 \%)$ and natural pastures (28\%) (Ladagnous and Le Bec 1997). The lagoon is permanently connected with the Mediterranean Sea by three large artificial openings in the eastern part of the lagoon. The main area of investigation is the western basin of the lagoon which receives freshwater from two karstic springs all year round (Figure 1b). The mean water flows are $3.0 \times 10^{5} \mathrm{~m}^{3} \mathrm{~d}^{-1}$ and $2.0 \times 10^{5} \mathrm{~m}^{3}$ $\mathrm{d}^{-1}$ for the springs Font Estramar and Font Dame, respectively (Arnaud 1968; Fleury et al. 2007). A sewage treatment plant discharges treated wastewater into the basin from Salses-le-Château village (3500 inhabitants).

Nutrient fluxes from the potential sources in La Palme lagoon were determined in a concurrent study (Rodellas et al. 2018). Estimated $\mathrm{NO}_{3}$ - fluxes were 220 - $1200 \mathrm{~mol} \mathrm{~d}^{-1}$ for karstic groundwater discharge and $19-130 \mathrm{~mol} \mathrm{~d}$ 1 for sewage effluent, whereas $\mathrm{NO}_{3}$ - inputs from porewater fluxes and diffusion were shown to be negligible. $\mathrm{NH}_{4}{ }^{+}$fluxes were $1-12 \mathrm{~mol} \mathrm{~d}^{-1}, 1900-5500 \mathrm{~mol}$ $\mathrm{d}^{-1}, 0.5-4 \mathrm{~mol} \mathrm{~d}^{-1}$ and $3-5 \mathrm{~mol} \mathrm{~d}^{-1}$ for karstic groundwater, porewater fluxes, sewage effluent and diffusion, respectively. Karstic groundwater represents thus a major source of $\mathrm{NO}_{3}$, while porewater fluxes are the main source of $\mathrm{NH}_{4}{ }^{+}$to La Palme lagoon (by > three orders of magnitude). Nitrogen inputs from diffusion were negligible compared to advective porewater fluxes, and thus the porewater source is assumed to represent chiefly advective porewater input.

In addition, we do not consider atmospheric nitrogen fixation in this study because it is a minor process in temperate systems (McGlathery et al. 1998; Welsh 2000), in contrast to the (sub)tropics where fixation plays a major role (Patriquin and Knowles 1972; Hansen et al. 2000). Whilst seawater can be a source of nitrogen in some cases (Capone 2008; Voss et al. 2011), the inputs of nitrogen from seawater are negligible in this study due to the reduced concentration in Mediterranean seawater (Siokou-Frangou et al. 2010; Pasqueron De Fommervault et al. 2015) and the limited exchange 
between the lagoon and the sea. However, seawater inflow is a pathway for external carbon.

\subsection{Sample collection and analysis}

\subsubsection{Water}

Fieldwork was conducted in June 2016, November 2016 and June 2017 in both lagoons, and additionally in April 2017 in La Palme lagoon. Temperature and salinity data were measured with a pre-calibrated WTW Multi 3430 probe (precision, $\pm 0.5 \%$ ). Lagoon surface water samples were collected with a 1-L widemouth Nalgene bottle along the salinity gradient. A push-point piezometer was used to collect $20 \mathrm{~mL}$ of porewater samples in the lagoon at 5, 10, 15 and $20 \mathrm{~cm}$ depth (e.g. Niencheski et al. 2007). Samples were preserved with $\mathrm{HgCl}_{2}\left(6 \mathrm{~g} \mathrm{l}^{-1}\right)$ to prevent bacterial activity for ammonium $\left(\mathrm{NH}_{4}{ }^{+}\right)$, nitrate + nitrite $\left(\mathrm{NO}_{\mathrm{x}}=\mathrm{NO}_{3}^{-}+\mathrm{NO}_{2}^{-}\right)$and phosphate $\left(\mathrm{PO}_{4}{ }^{3-}\right)$ analyses (Kirkwood 1992). Nitrate and nitrite were not separately quantified and defined here as nitrate $\left(\mathrm{NO}_{3}^{-}\right)$.

$\mathrm{NO}_{3}^{-}$and $\mathrm{PO}_{4}^{3-}$ concentrations were measured by colorimetric method on a Technicon AutoAnalyser $®$ II with detection limits of $0.05 \mu \mathrm{mol} \mathrm{L} \mathrm{L}^{-1}$ and $0.02 \mu \mathrm{mol} \mathrm{L} \mathrm{L}^{-1}$ for $\mathrm{NO}_{3}{ }^{-}$and $\mathrm{PO}_{4}{ }^{3-}$, respectively (Raimbault et al. 1999; Aminot and Kérouel 2007). $\mathrm{NH}_{4}{ }^{+}$concentrations were determined on diluted samples (4 to 10 times) with a Turner Designs TD-700 Fluorometer (detection limit: $0.05 \mu \mathrm{mol} \mathrm{L}-1$ ) (Holmes et al. 1999). In the springs and sewage effluents, the $\delta^{15} \mathrm{~N}^{-\mathrm{NO}_{3}}{ }^{-}$in water column was analysed. In the sediment porewater, $\mathrm{NO}_{3}{ }^{-}$ concentrations were very low, and therefore the measured $\delta^{15} \mathrm{~N}$ of total DIN $\left(\mathrm{NH}_{4}{ }^{+}+\mathrm{NO}_{3}{ }^{-}\right)$is taken to represent $\mathrm{NH}_{4}{ }^{+}$. The $\delta^{15} \mathrm{~N}$ of $\mathrm{NO}_{3}{ }^{-}$and DIN were determined following the reduction / diffusion method (Sigman et al. 1997; Holmes et al. 1998; Raimbault et al. 1999). The method involves the conversion of nitrate to ammonium using Devarda's alloy and the diffusion of ammonia gas onto an acidified filter. Note that due low nutrient concentrations in the lagoon water and seawater samples, nitrogen isotopic signatures were not measured. 
Lagoon surface water samples for $\delta^{13} \mathrm{C}$-DIC analyses were collected along the salinity gradient with a $100 \mathrm{~mL}$ glass vial. Samples were collected underwater to prevent atmospheric exchange, and the vials were immediately crimp-sealed with rubber serum stoppers and open top aluminium caps and then poisoned with $\mathrm{HgCl}_{2}$ to prevent bacterial activity. The $\delta^{13} \mathrm{C}$ of DIC was measured following the procedure of Miyajima et al. (1995). A headspace of 3 $\mathrm{mL}$ is created inside each airtight glass vials with pure helium gas and each sample is then acidified with $10 \mathrm{~N} \mathrm{H}_{2} \mathrm{SO}_{4}$. After the original DIC has equilibrated with the headspace gas, a portion of this headspace gas is collected with a glass syringe for injection into a mass spectrometer.

\subsubsection{Primary producers}

During each campaign, dominant macrophytes were collected in the springs, at the outlets of the sewage treatment facilities and at multiple sites in the lagoons along the salinity gradient. Leaves were sampled nondiscriminately from the dominant species observed (Zostera noltii, Ruppia cirrhosa, Ulva sp, Phragmites communis). Samples were rinsed with deionised water, bagged and transported on ice to the laboratory, where they were ovendried at $60{ }^{\circ} \mathrm{C}$, ground and homogenized with a mortar and pestle. Approximately $1 \mathrm{mg}$ of the ground samples was analysed for $\delta^{15} \mathrm{~N}$ and $\delta^{13} \mathrm{C}$. Each sample was acidified with $50 \mu \mathrm{L}$ of $0.25 \mathrm{~N} \mathrm{H}_{2} \mathrm{SO}_{4}$ to eliminate carbonates, which may interfere with $\delta^{13} \mathrm{C}$ measurements. To assess if variability in the signatures is linked to species differences, signatures in different species collected at the same location were compared. Particulate organic matter (POM), predominantly representing phytoplankton (Carlier et al. 2007, 2009), was sampled in the springs, sewage and the lagoons. 0.4 to $1 \mathrm{~L}$ of water samples were filtered through GF/F filters $(0.7 \mu \mathrm{m})$ under moderate vacuum until clogging. Filters were kept frozen until analyses on mass spectrometry.

All isotope analyses (in primary producers and water column) were carried out at the Mediterranean Institute of Oceanography (Marseille) using elemental analyzer mass spectrometer Integra CN Sercon (Raimbault et al. 2008; Lacoste et al. 2016). Following common notion, the isotopic composition $\left(\delta^{15} \mathrm{~N}\right.$ or $\left.\delta^{13} \mathrm{C}\right)$ was expressed as relative difference between isotopic ratios in 
sample and in conventional standards (atmospheric $\mathrm{N}_{2}$ for nitrogen and Vienna Pee Dee Belemnite for carbon):

$$
\delta^{15} \mathrm{~N} \text { or } \delta^{13} \mathrm{C}(\% 0)=\left(R_{\text {sample }} / R_{\text {standard }}-1\right) \times 1000
$$

where $\mathrm{R}$ is the ratio ${ }^{15} \mathrm{~N} /{ }^{14} \mathrm{~N}$ or ${ }^{13} \mathrm{C} /{ }^{12} \mathrm{C}$. The precisions of replicate analyses were $0.5 \%$ and $0.3 \%$ for $\delta^{15} \mathrm{~N}$ and $\delta^{13} \mathrm{C}$, respectively.

\section{Results}

\section{$3.1 \mathrm{NO}_{3}-$ and $\mathrm{NH}_{4}{ }^{+}$concentrations}

Overall, $\mathrm{NO}_{3}-$ concentrations in the lagoon systems decreased with increasing salinity, and highest concentrations were observed in the springs and the sewage outlets (Figure 2). Surface water $\mathrm{NO}_{3}$ concentrations in the lagoons ranged from below the detection limit $(0.05 \mu \mathrm{mol} \mathrm{L}-1)$ to $7.8 \mu \mathrm{mol} \mathrm{L}^{-1}$ and between 0.1 and $54.5 \mu \mathrm{mol} \mathrm{L}{ }^{-1}$ in La Palme lagoon and Salses-Leucate lagoon, respectively (Figure $2 \mathrm{a}$ and $\mathrm{b}$ ). In the streams draining the springs and downstream of the sewage treatment facilities, the concentrations were significantly elevated over lagoon values (34.0 - $65.0 \mu \mathrm{mol} \mathrm{L}{ }^{-1} \mathrm{La}$ Palme lagoon; 0.3 - $41.7 \mu \mathrm{mol} \mathrm{L}{ }^{-1}$ Salses-Leucate lagoon). In June 2017, the $\mathrm{NO}_{3}{ }^{-}$concentration measured at the outlet of the sewage in La Palme lagoon was exceptionally high at $522 \mu \mathrm{mol} \mathrm{L}-1$.

Unlike $\mathrm{NO}_{3}$, the $\mathrm{NH}_{4}{ }^{+}$concentrations did not show any clear spatial pattern in either lagoon. The concentrations ranged from 0.8 to $36 \mu \mathrm{mol} \mathrm{L}^{-1}$ in La Palme lagoon and from 0.2 to $30.4 \mu \mathrm{mol} \mathrm{L}^{-1}$ in Salses-Leucate lagoon and in the streams (creeks) (Figure 2c and d). The springs showed significantly lower $\mathrm{NH}_{4}{ }^{+}$concentrations, while the concentrations in the sewage and the porewaters were markedly higher, particularly in Salses-Leucate lagoon.

\subsection{Source isotopic signatures}

Karstic groundwater $\delta^{15} \mathrm{~N}-\mathrm{NO}_{3}{ }^{-}$were $3.1 \pm 2.1 \%$ o $(\mathrm{n}=4)$ and $1.0 \pm 1.2 \% 0$ $(\mathrm{n}=5)$ in La Palme and Salses-Leucate lagoons, respectively. $\mathrm{NO}_{3}{ }^{-}$samples from sewage effluents were enriched in ${ }^{15} \mathrm{~N}$ with a mean $\delta^{15} \mathrm{~N}-\mathrm{NO}_{3}{ }^{-}$of $16.4 \pm 4.5 \%$ o $(n=3)$ in La Palme lagoon and $17.6 \pm 3.7 \%(n=2)$ in Salses-Leucate lagoon. Porewater $\delta^{15} \mathrm{~N}$-DIN $\left(\mathrm{NO}_{3}{ }^{-}+\mathrm{NH}_{4}{ }^{+}\right)$values were depleted compared to those of 
sewage with mean values of $7.1 \pm 3.3 \%$ o $(n=12)$ and $6.4 \pm 2.1 \%$ o $(n=3)$ in La Palme and Salses-Leucate lagoons, respectively. With exception of a small overlap of groundwater and lagoon porewater in La Palme lagoon, in general the signatures of the sources (karstic groundwater, porewater and sewage) are sufficiently different to identify the nitrogen source used for primary producers to support their growth (Figure 3a). Nitrogen isotopic signatures of lagoon waters and seawater were below detection limit of our methods due to the low nitrogen concentrations in these surface waters.

The observed nitrogen isotopic signatures in the different sources are in good agreement with previously reported ranges: $\delta^{15} \mathrm{~N}$ commonly ranges between +10 and $+20 \%$ for sewage effluents, between +2 and $+5 \%$ o for porewater, and between +2 and $+8 \%$ for groundwater from natural soils (Figure 3a) (Cole et al., 2005; Kendall et al., 2007). Processes such as $\mathrm{NH}_{4}{ }^{+}$ volatilization and denitrification have been identified previously as the main reason for the elevated signatures of $\delta^{15} \mathrm{~N}$ in sewage effluents (Aravena et al., 1993). The nitrogen signatures in porewaters are strongly affected by the drainage, vegetation, plant litter, land use and climate (Kendall and Aravena 2000). The $\delta^{15} \mathrm{~N}^{-\mathrm{NO}_{3}}{ }^{-}$signatures of the karstic groundwater, which is lower than the other sources in both lagoons, depend strongly on the land use and the nitrogen delivery (Cole et al. 2006). For instance, groundwater heavily influenced by septic system or wastewater can become enriched in $\delta^{15} \mathrm{~N}$ (between +10 and $+20 \%$ ), whereas the $\delta^{15} \mathrm{~N}$ signature can be lower (between -3 and $+3 \%$ ) for groundwater $\mathrm{NO}_{3}-$ derived from fertilizers (Kendall et al. 2007). The relatively low $\delta^{15} \mathrm{~N}^{-\mathrm{NO}_{3}}$ of the karstic groundwater (1-3\%) reflects the negligible influence of wastewater in the watershed due to the central sewage system (as opposed to septic tanks) not affecting groundwater loading on one hand and a low population pressure in general on the other.

Similar to nitrogen isotopes, the carbon signatures of the three analyzed DIC sources were distinct from another (Figure 3b). Karstic groundwater had average $\delta^{13} \mathrm{C}$ values of $-8.5 \pm 1.0 \%$ o $(\mathrm{n}=4)$ and $-8.0 \pm 0.4 \%$ o $(\mathrm{n}=5)$ in La Palme and Salses-Leucate lagoons, respectively, which agree with literature values (e.g. -13.5 to $-6.9 \%$ karstic catchment Changjiang River, China; Li et al. 2010). Sewage $\delta^{13} \mathrm{C}$-DIC was depleted with an average value of - 
$12.5 \pm 1.7 \%$ o $(n=3)$ in La Palme lagoon and $-10.5 \% 0(n=1)$ in Salses-Leucate lagoon, again comparable to previously reported values e.g. for sewageinfluenced estuaries (-15 to -11\%; Hellings et al. 2001; Barros et al. 2010). Porewater samples for $\delta^{13} \mathrm{C}$-DIC analyses could not be collected due to $\mathrm{CO}_{2}$ volatility; previous studies reported $\delta^{13} \mathrm{C}$-DIC values between -18 and -9\% in marine and coastal porewaters (Yang et al. 2008). Seawater had a $\delta^{13} \mathrm{C}$-DIC of $0.6 \pm 0.5 \%$ o $(n=3)$ in La Palme and 0.9\%o in Salses-Leucate lagoon, which agrees with previously reported values (ca. 0\%; Raven et al. 2002). The lighter $\delta^{13} \mathrm{C}$-DIC of groundwater reflects mineralisation of organic matter combined with the weathering of carbonate minerals, while the seawater DIC is in isotopic equilibrium with the atmospheric $\mathrm{CO}_{2}$ (Chanton and Lewis 1999).

The $\delta^{13} \mathrm{C}$-DIC signatures measured in lagoon waters increase with increasing salinity in both lagoons (Figure $4 \mathrm{a}$ and b), ranging from -8.5 to $0.2 \%$ in La Palme lagoon and -7.5 to $1.7 \%$ in Salses-Leucate lagoon, similar to previous observations (e.g. -12 to $0 \%$ in Apalachicola Bay, Florida (Chanton and Lewis 1999) or in estuaries (Gillikin et al. 2006) and coastal bays (Barros et al. 2010)). $\delta^{13} \mathrm{C}$-DIC in lagoon waters seemed to be explained by the mixing of freshwater (karstic groundwater) and marine sources (see section 4.2.1).

\section{$3.3 \delta^{15} \mathrm{~N}$ in macrophytes and POM}

Macrophyte $\delta^{15} \mathrm{~N}$ signatures ranged from -3.0 to $12.6 \%$ in La Palme lagoon and from -1.8 to $9.9 \%$ in Salses-Leucate lagoon, but did not show a clear pattern with respect to salinity in either lagoon (Figure $5 \mathrm{a}$ and b). In La Palme lagoon, macrophytes collected in June 2017 at the northern part of the lagoon and close to the sewage and spring sources showed significantly elevated isotopic signatures over otherwise generally stable values (Figure 5a). Macrophytes sampled in the karstic springs had lower $\delta^{15} \mathrm{~N}$ in La Palme lagoon (mean: $0.0 \pm 2.3 \%$; $n=4$ ) and in Salses-Leucate lagoon (mean: $0.4 \pm$ $1.6 \% 0 ; n=6$ ) while higher signatures were measured at the sewage outlets (11.4 $\pm 2.5 \%$ in La Palme lagoon and 18.1\%o ; $n=1$ in Salses-Leucate lagoon).

Overall, the $\delta^{15} \mathrm{~N}$ of POM showed larger variability compared to that of macrophytes, but like in macrophytes, no clear spatial pattern was observed in the distribution of $\delta^{15} \mathrm{~N}-\mathrm{POM}$ (representing phytoplankton) in either lagoon 
(Figure 5c and d). The $\delta^{15} \mathrm{~N}$ in POM collected at the karstic springs were lower $(0.9 \pm 3.9 \%$ o $(n=3)$ in La Palme lagoon and $1.7 \pm 5.2 \%$ in Salses-Leucate lagoon) while the signatures from the sewage treatment plants were markedly high $(11.7 \pm 4.2 \%$ o $(n=3)$ in La Palme lagoon and 10.9\%o $(n=1)$ in SalsesLeucate lagoon).

Overall, the $\delta^{15} \mathrm{~N}$ in macrophytes and POM measured in this study were in very good agreement with previous measurements from the same lagoons (Carlier et al. 2007, 2009).

\section{$3.4 \delta^{13} \mathrm{C}$ in macrophytes and POM}

The $\delta^{13} \mathrm{C}$ in macrophytes showed an overall increase with increasing salinity in both lagoons (Figure $6 \mathrm{a}$ and b), similar to the trend shown by $\delta^{13} \mathrm{C}$ DIC signatures in lagoon waters. $\delta^{13} \mathrm{C}$ was markedly lower in macrophytes collected in springs $(-33.6 \pm 2.0 \%(n=4)$ in La Palme lagoon and $-34.4 \pm 2.5 \% 0$ $(n=5)$ in Salses-Leucate lagoon) and at the outlet of the sewage treatment plants (-26.7 to $-10.4 \%$ La Palme lagoon; -16.6 to $-7.5 \%$ Salse-Leucate lagoon).

In La Palme lagoon, $\delta^{13} \mathrm{C}$-POM showed also an increase with increasing salinity (Figure 6c). In the spring and sewage respectively, $\delta^{13} \mathrm{C}-\mathrm{POM}$ was -29.4 $\pm 2.9 \%$ and $-26.5 \pm 2.6 \%$. In Salses-Leucate lagoon, the $\delta^{13} \mathrm{C}-\mathrm{POM}$ values showed minor increase along the salinity gradient compared to the values in La Palme lagoon (Figure 6d). Lower signatures were however observed in the springs (mean: $-29.7 \pm 3.6 \%$; $n=6)$ and sewage $(-26.9 \%$ ).

Similar to nitrogen isotopes, carbon isotope ratios measured in macrophytes and POM in this study are consistent with previous observations in the same lagoons (Carlier et al., 2007, 2009) and at other Mediterranean sites (Lepoint et al. 2000; Vizzini and Mazzola 2003).

\subsection{Interspecific variations in isotopic signature in macrophytes}

Comparison of $\delta^{15} \mathrm{~N}$ and $\delta^{13} \mathrm{C}$ of macrophytes of individual species (Ulva sp, Ruppia cirrhosa, Zostera noltii and Acetabularia acetabulum) indicated low interspecific variation for both $\delta^{15} \mathrm{~N}(0.1-2.0 \%)$ and $\delta^{13} \mathrm{C}(0.4-4.5 \%)$. 
Previous studies also report small differences in isotopic signatures of macrophytes among different species (Carlier et al. 2007; Derse et al. 2007). We therefore consider the pooled macrophyte isotope data in our interpretation.

\section{Discussion}

\subsection{Processes affecting macrophyte and phytoplankton $\delta^{15} \mathrm{~N}$}

\subsubsection{Nitrogen concentrations in lagoons and sources}

The non-linear decrease in $\mathrm{NO}_{3}{ }^{-}$concentrations with increasing salinity observed in both La Palme and Salses-Leucate lagoons indicates (a) a low salinity source term (b) efficient $\mathrm{NO}_{3}-$ removal along the salinity gradient (Figure $2 \mathrm{a}$ and $\mathrm{b}$ ). Biological uptake is likely the main process removing $\mathrm{NO}_{3}$ from the lagoons (Liu et al. 2009). Denitrification, which is the only other relevant processes removing $\mathrm{NO}_{3}^{-}$in aquatic systems, is unlikely to occur as surface water oxygen concentrations are close to (or above) saturation (9.3 \pm $3.7 \mathrm{mg} \mathrm{L}^{-1}$ in La Palme lagoon ; $8.5 \pm 2.7 \mathrm{mg} \mathrm{L}^{-1}$ in Salses-Leucate lagoon) (Capone 2008; Leffler and Welker 2013).

Typical for coastal environments, $\mathrm{NH}_{4}{ }^{+}$concentrations are 3-7 times higher in the sediment than in the overlying water due to mineralization of organic matter as well as dissimilatory nitrate reduction to ammonium (DNRA) (An and Gardner 2002; Kim et al. 2017). The inhibition of nitrification, due to anoxia in sediment, enhances this accumulation of $\mathrm{NH}_{4}{ }^{+}$(Christensen et al. 2000), and these high $\mathrm{NH}_{4}{ }^{+}$concentrations in sediment are available for remobilisation. In the karstic groundwater springs, sewage effluent and the lagoon, aerobic conditions inhibit $\mathrm{NO}_{3}^{-}$conversion to $\mathrm{NH}_{4}^{+}$via DNRA (Christensen et al. 2000).

At salinity below 20 (La Palme lagoon) and 30 (Salses-Leucate lagoon), DIN:DIP ratios were mostly above the Redfield Ratio due to nitrogen-enriched inputs from groundwater springs and/or sewage effluents (Figure 2e and f). This indicates that primary production is P-limited in low salinity parts of the lagoons, and N-limited for the more saline parts. 


\subsubsection{Nitrogen uptake and associated isotopic fractionation}

Phytoplankton assimilates DIN from the water column (Bradley et al. 2010). Permanently submerged species take up nutrients almost exclusively at their leaves (Ruiz and Velasco 2009; Zhao et al. 2013). Uptake at leaves also accounts for about $80 \%$ of total nitrogen acquisition by non-permanently submerged phragmites (Lee and Dunton 1999). The majority of the macrophytes analysed herein are permanently submerged species, with some samples collected close to the banks including a small number of phragmite specimen. Leaf samples analysed in this study are thus assumed to source their nitrogen from the water column like phytoplankton.

Macrophytes can assimilate water column nitrogen even at very low concentrations (Lee and Dunton 1999). Isotope fractionation during uptake depends significantly on the availability of nitrogen, increasing with increasing nitrogen concentrations, and thus potentially altering isotopic signatures in particular at nitrogen-rich systems / locations (Fry 2003; Benson et al. 2008). The higher DIN:DIP ratios in the low salinity parts of both lagoons (above the Redfield ratios; Figure 2) indicate that these systems are not N-limited, and thus isotopic fractionation may have occurred, resulting in lower $\delta^{15} \mathrm{~N}$ in primary producers relative to the isotopic ratios found in the water column.

Assuming that the $\delta^{15} \mathrm{~N}$ signature of the water column $\mathrm{NO}_{3}^{-}\left(\delta^{15} \mathrm{~N}_{\text {pool }}\right)$ is representative of the signature taken up by the primary producers, the $\delta^{15} \mathrm{~N}$ signature of the primary producers $\left(\delta^{15} \mathrm{~N}_{\text {prod }}\right)$ can be expressed as:

$$
\delta^{15} \mathrm{~N}_{\text {prod }}=\delta^{15} \mathrm{NO}_{3}^{-} \text {pool }-\varepsilon_{\text {prod }}
$$

where $\varepsilon_{\text {prod }}$ represents the fractionation factor associated with $\mathrm{NO}_{3}^{-}$uptake (Fry 2003). We constrain the effect of fractionation by estimating $\varepsilon_{\text {prod }}$ for macrophytes and phytoplankton using concurrently collected $\delta^{15} \mathrm{~N}$ in primary producers and in the water column from the groundwater sources where highest nutrient concentrations are found and thus maximum $\varepsilon_{\text {prod }}$ for this system are expected (Evans 2001; Cohen and Bradham 2010). Furthermore, groundwater has a relatively constant nitrogen isotopic signature. The primary producers are thus permanently in contact with the same type of water making these sites reliable 'reference' stations. 
Maximum fractionation factors calculated for all sampling campaigns in the 3 different springs ( 1 in La Palme lagoon and 2 in Salses-Leucate lagoon) were $4.7 \%$ and $1.4 \%$ o for macrophytes and phytoplankton, respectively. These values are close to the fractionation factor of macrophytes from springfed rivers (1.9 to 3.6\%; Brabandere et al. 2007) and that of phytoplankton (1\%); Montoya and McCarthy 1995). Maximum fractionation factors observed for aquatic macrophytes are on the order of 5\%o (Altabet and Francois 1994; Kohzu et al. 2008). We thus assume that isotopic fractionation during nitrogen uptake by primary producers will be considerably lower than $5 \%$ in the lagoons where DIN concentrations are significantly lower.

A fully quantitative analysis of relative contributions of sources would require a detailed knowledge of the relationship of fractionation as a function of nutrient concentration and the potential spatial variability of macrophytes and phytoplankton species with salinity (Brabandere et al. 2007). Nitrogen isotope data from lagoon water is not available due to low nitrogen concentrations in the studied near-natural lagoons. This prevents us thus from being able to construct a full isotopic balance in lagoon water and presents an important limitation of our approach, which is likely to be encountered in many natural oligotrophic ecosystems. In order to fully quantify the nutrient transfer to primary producers, the nutrient concentration would have to be measured quasi-continuously because the fractionation factor depends on the concentration at the time of uptake, which cannot be assumed to be constant over the lifetime of the organisms in most lagoon ecosystems. These limitations do not exist in the same way in eutrophied systems with relatively constant isotopic signatures.

Finally, the relative contribution of the three different sources supplying nitrogen to support primary producers growth (karstic groundwater discharge, advective porewater fluxes and sewage effluent) cannot be identified by using only the signatures of one stable isotope (i.e. $\delta^{15} \mathrm{~N}$ ). Important conclusions can nevertheless be drawn on the relative contributions of different endmembers. 


\subsubsection{Nitrogen sources for primary producers}

Generally, the $\delta^{15} \mathrm{~N}$ of macrophytes and phytoplankton closely match the nitrogen isotopic signatures of the karstic groundwater and porewater sources, with some exceptions (Figure 7 ). $\delta^{15} \mathrm{~N}$ in macrophytes slightly below source signatures was observed in La Palme lagoon in June 2016 and is consistent with a small fractionation effect during groundwater-borne nitrogen uptake. Overall, at fractionation below 5\%, macrophytes and phytoplankton must have sourced the majority of their nitrogen from fresh karstic groundwater and/or porewater fluxes.

The $\delta^{15} \mathrm{~N}^{-\mathrm{NO}_{3}}{ }^{-}$of the karstic groundwater and the $\delta^{15} \mathrm{~N}-\mathrm{DIN}$ (mainly $\mathrm{NH}_{4}{ }^{+}$) of porewater are relatively close to each other in La Palme lagoon (Figure 7a), making it difficult to differentiate the relative contributions from these two sources from their isotope signature alone in this lagoon. In SalsesLeucate lagoon however, karstic groundwater and porewater are differentiated isotopically (Figure 7b).

In Salses-Leucate lagoon, those samples collected closer to the groundwater springs typically have signatures close to or below the $\delta^{15} \mathrm{~N}$ signature of karstic groundwater (macrophytes in June 2016 and POM in June 2017; Figure 7b), suggesting that at these locations, primary producers' uptake their nitrogen predominantly from the karstic groundwater. The influence of karstic groundwater inputs into this lagoon is restricted to the area close to the karstic springs, due to smaller inflow from karstic groundwater (inflow of karstic discharge estimated to account for ca. $0.008 \%$ of lagoon volume per day; Fleury et al. (2007)), larger size and the better connection with the ocean, as shown by the salinity distribution (Figure 1b). Similarly, the isotope signatures indicate a minor role of karstic groundwater in nitrogen supply, suggesting that primary producers in this large lagoon source most of their nitrogen from the porewater source. The isotope data from La Palme lagoon corroborates overall the relatively larger impact of karstic groundwater in primary producers, mainly due to the larger groundwater inflow relative to the lagoon size (ca. 1\% of lagoon volume per day) compared to Salses-Leucate lagoon and the restricted exchange with the sea, as also indicated by the salinity distribution (Figure 1a; Stieglitz et al. 2013). The contrasting 
hydrodynamic conditions in La Palme and Salses-Leucate lagoons explain thus the differences of isotopic signatures in the primary producers from these two lagoons.

Porewaters and sewage effluent are sources of $\mathrm{NH}_{4}{ }^{+}$to the lagoons. These two sources can easily be differentiated by their nitrogen signatures, with porewater $\delta^{15} \mathrm{~N}-\mathrm{NH}_{4}{ }^{+}$at $7.1 \pm 3.3 \%$ in La Palme lagoon and $6.4 \pm 2.1 \%$ in Salses-Leucate lagoon significantly lower than in sewage effluent (30.6\%o in La Palme lagoon and 28.3\%o in Salses-Leucate lagoon). The nitrogen signatures in primary producers in both lagoons reflect closely the $\delta^{15} \mathrm{~N}-\mathrm{NH}_{4}{ }^{+}$of porewater most of the time (Figure 7). Porewater fluxes often represent a major source of dissolved inorganic nitrogen to coastal environments, including lagoons, bays, estuaries and ocean basins (e.g. Kroeger et al. 2007; Street et al. 2008; Rodellas et al. 2015; Sadat-Noori et al. 2016). The dynamics of this input can vary significantly according to the hydraulic conditions, tidal forcing and the distance of the fresh and saline mixing zone from the shore (Taniguchi et al. 2006; Sadat-Noori et al. 2016).

The high $\mathrm{NH}_{4}{ }^{+}$fluxes from porewater fluxes (Rodellas et al. 2018) combined with our isotopic signature data indicate that porewater fluxes are major source of $\mathrm{NH}_{4}+$. The volumetrically large contribution of nitrogen in the form of $\mathrm{NH}_{4}{ }^{+}$has important implications for lagoon primary production, because phytoplankton and macrophytes preferentially take up $\mathrm{NH}_{4}{ }^{+}$over $\mathrm{NO}_{3}$ - due to reduced energetic costs (Lotze and Schramm 2000; Middelburg and Nieuwenhuize 2000; Cohen and Fong 2005). Uptake of $\mathrm{NO}_{3}^{-}$is more energetically demanding, because it requires the synthesis of $\mathrm{NO}_{3}{ }^{-}$and $\mathrm{NO}_{2}{ }^{-}$ reductases and associative active transport systems (Syrett 1981).

Both La Palme and Salses-Leucate lagoons are shallow, allowing proliferous macrophytes to develop within the euphotic zone $(>60 \%$ dense macrophyte cover (Ifremer 2014). In such coastal lagoons, nutrients are efficiently incorporated into macrophytes biomass. In both lagoons, N/P ratios are relatively high in comparison to the Redfield ratio (Figure 2). In La Palme lagoon, N/P ratios above the Redfield ratio in the low-salinity areas indicate influence of new nitrogen inputs (mainly $\mathrm{NO}_{3}^{-}$) from the karstic groundwater, while high N/P ratio at mid-salinity in Salses-Leucate are a result of inputs of 
(regenerated) porewater $\mathrm{NH}_{4}^{+}$. Whilst nitrogen is often a limiting factor in coastal systems, this is not the case in these lagoons due to the inputs of nitrogen from karstic groundwater and porewater fluxes. Groundwater inputs are thus particularly important in coastal lagoons like La Palme and SalsesLeucate lagoons where surface inputs are negligible.

High $\delta^{15} \mathrm{~N}$ signatures in macrophytes collected in La Palme lagoon in June 2017 (above 8\%; when $\mathrm{NO}_{3}{ }^{-}$concentration at the outlet of the sewage was exceptionally high; see below) and in phytoplankton (POM) in November 2016 in Salses-Leucate lagoon (Figure 7) suggest major contributions from sewage effluent to support primary production during these periods. High signatures in La Palme lagoon in June 2017 coincide with the summer season, which is the main tourist season in the region, resulting in an increase in local population and thus, presumably, in the amount of sewage effluent. Indeed, during this period, an unusually high $\mathrm{NO}_{3}{ }^{-}$concentration was measured in the sewage effluent $\left(522.4 \mu \mathrm{mol} \mathrm{L} \mathrm{L}^{-1}\right)$. This suggests that nitrogen fluxes from sewage effluent are higher in this season, and thus the uptake of sewagedriven nitrogen is likely more available for primary producers. Whereas $\mathrm{NH}_{4}{ }^{+}$ volatilization could have contributed to increasing the $\delta^{15} \mathrm{~N}$ of the remaining $\mathrm{N}$ pool resulting in ${ }^{15} \mathrm{~N}$ enrichment of the macrophytes (Kendall et al. 2007), they alone do not explain the high $\delta^{15} \mathrm{~N}$ of the lagoon macrophytes in June 2017. $\mathrm{NH}_{4}{ }^{+}$volatilization occurs under alkaline condition and high temperature, which are not found in either lagoon (Capone 2008; Das Gupta et al. 2016). Similarly, phytoplankton collected at the outlet of the sewage treatment plants has elevated $\delta^{15} \mathrm{~N}$ signatures, also suggesting that it assimilated the ${ }^{15} \mathrm{~N}$ enriched nitrogen of the treated wastewater (Figure $5 c$ and $d$ ).

When excluding the exceptional high values in June 2017, the $\delta^{15} \mathrm{~N}$ signature of macrophytes fluctuate overall within a small range, particularly for Salses-Leucate lagoon (e.g. 2.1 to 7\%o in Salses-Leucate lagoon), whereas that of phytoplankton showed larger variability (e.g. -1.8 to 9.9\%o in SalsesLeucate lagoon) (Figure 5), suggesting that macrophytes are better timeintegrative measures of nitrogen input than phytoplankton (Dudley and Shima 2010). Similar observations were reported in estuaries by Cole et al. (2005). With a short life span (from a few days to a week) and large mobility of 
phytoplankton, its nitrogen signature will change at the short-term scale of hydrological events (Cloern et al. 2002). In contrast, (rooted) macrophytes integrate the isotopic signatures of the nitrogen sources over their longer lifetime, which usually ranges from 15 days to 160 days (Hemminga et al. 1999; Marbà et al. 2006). Their signatures represent thus a proxy of the longer-term average source signatures (Lepoint et al. 2004; Derse et al. 2007).

The different timescales of nutrient integration into macrophytes and phytoplankton allow to assess the temporal variability of nutrient inputs. Nitrogen supplied to the lagoon several weeks before the collection of samples cannot be 'tracked' in phytoplankton samples, but it is integrated in macrophyte records. For instance, the relatively higher $\delta^{15} \mathrm{~N}$ signatures in macrophytes than in phytoplankton in La Palme lagoon in June 2017 indicates a high nutrient supply from sewage effluent for several weeks before the sampling campaign, which must have ceased some days before the sampling campaign for it not to be reflected in the corresponding phytoplankton record (Figure 7a). Similarly, the high $\delta^{15} \mathrm{~N}$ signature in phytoplankton in SalsesLeucate lagoon (November 2016), which is not recorded in macrophyte signatures, may indicate only recent sewage input that have not (yet) affected macrophyte signatures (Figure 7b).

Overall, the combination of $\delta^{15} \mathrm{~N}$ records in long-lived macrophytes and short-lived phytoplankton provides insights into the dynamics of nitrogen input and primary production in coastal ecosystems. This approach is a particularly useful additional tool in groundwater studies, where commonly large uncertainties in quantifying nitrogen fluxes (see section 2.1) result in uncertain evaluation of the 'true' impact of groundwater-derived nutrient fluxes on coastal ecosystems.

\subsubsection{Contribution of different nitrogen sources}

As noted above, the lack of an accurate characterization of fractionation factors and the identification of three major nitrogen sources prevents a fully quantitative assessment of the relative contribution of nitrogen sources. However, a qualitative assessment of the relevance of groundwater and porewater fluxes as a nitrogen source to primary producers (relative to 
sewage inputs) can be obtained by treating both advective water fluxes as a single source (groundwater+porewater). Indeed, the nitrogen isotopic signatures of the groundwater and porewater were relatively close to each other, particularly in La Palme lagoon. The contribution of the groundwater+porewater source can be estimated using the isotope mixing equation (Phillips and Gregg 2003):

$$
\delta^{15} \mathrm{~N}_{p p}=f \times \delta^{15} \mathrm{~N}_{g w+p o r}+(1-f) \times \delta^{15} \mathrm{~N}_{\text {sew }}
$$

where $f$ corresponds to the fraction of groundwater+porewater source, $\delta^{15} \mathrm{~N}_{p p}$ represents the nitrogen isotopic signatures in the primary producers and $\delta^{15} \mathrm{~N}_{g w+\text { por }}$ and $\mathrm{N}_{\text {sew }}$ are the nitrogen isotopic signatures of the groundwater+porewater and sewage endmembers, respectively. Assuming a fractionation factor of $2.5 \%$ during the nitrogen uptake (see section 4.1 .2 ), the relative contribution of the groundwater+porewater source can be constrained by assuming that this source is exclusively dominated by the nitrogen signature of either karstic groundwater or porewater advection. The combination of groundwater and porewater fluxes would supply $76-100 \%$ and $60-94 \%$ of the nitrogen used to support primary producer growth in La Palme and Salses-Leucate lagoons, respectively. The remaining percentage accounts for the contribution of nitrogen from the sewage effluent. This qualitative assessment confirms that primary producers in both lagoons sourced most of their nitrogen from groundwater or porewater fluxes.

\subsection{Macrophyte and phytoplankton carbon uptake and isotope signature}

\subsubsection{Inorganic carbon sources and signature}

The role of groundwater and porewater fluxes as sources of DIC has previously been documented (Santos et al. 2012b; Atkins et al. 2013), constituting a major component of the carbon cycling in coastal ecosystems (Cai et al. 2003). The carbon isotope data in this study indicates that groundwater processes also play a major role in the carbon dynamics of Mediterranean lagoons.

The $\delta^{13} \mathrm{C}$-DIC values increase with increasing salinity in both lagoons and indicate binary and conservative mixing between a low salinity - low $\delta^{13} \mathrm{C}$ - 
DIC source (karstic groundwater) and a high salinity - high $\delta^{13} \mathrm{C}$-DIC source (marine / seawater in equilibrium with the atmosphere with respect to DIC) (Figure 4). However, some outliers in the relationship between the $\delta^{13} \mathrm{C}$ of DIC and salinity indicate that other processes may play minor role. For instance, DIC inputs from porewater fluxes influence the $\delta^{13} \mathrm{C}$-DIC signatures in lagoon waters (see below), uptake by primary producers increases the isotopic signatures of DIC due to preferential uptake of ${ }^{12} \mathrm{CO}_{2}$ over ${ }^{13} \mathrm{CO}_{2}$, and in contrast, respiration decreases the $\delta^{13} \mathrm{C}$-DIC due to input of lighter isotopes (Chanton and Lewis 1999).

Whereas the relationship between $\delta^{13} \mathrm{C}$-DIC and salinity in both lagoons suggests binary mixing between karstic groundwater and seawater, porewater is also likely an important source of DIC, given the mineralization of deposited organic matter in sediments and the high porewater fluxes of water and dissolved nutrients (Rodellas et al. 2018). Indeed, both the distribution of $\mathrm{NH}_{4}{ }^{+}$ concentrations in lagoon waters (Figure 2c and 2d) and the high $\mathrm{NH}_{4}{ }^{+}$ measured in porewaters supports an important mineralization of organic matter and the potential transfer of mineralization products into the water column.

Considering the DIC excess (relative to overlying lagoon waters) concentrations in porewaters from La Palme lagoon measured in a concurrent study (600 - $1400 \mu \mathrm{mol} \mathrm{L}-1$; C. Monnin, unpublished data) and the estimated porewaters flows $\left((42-89) \times 10^{3} \mathrm{~m}^{3} \mathrm{~d}^{-1}\right.$; Rodellas et al. 2018), DIC fluxes driven by porewater fluxes is on the order of $(20-120) \times 10^{3} \mathrm{~m}^{3} \mathrm{~d}^{-1}$. These inputs are comparable to the DIC fluxes supplied by karstic groundwater discharge to La Palme lagoon, which are $(20-170) \times 10^{3} \mathrm{~m}^{3} \mathrm{~d}^{-1}$ as derived from karstic groundwater flows $\left((3-25) \times 10^{3} \mathrm{~m}^{3} \mathrm{~d}^{-1}\right.$; Rodellas et al. 2018) and DIC concentrations in the karstic spring $\left(5900 \pm 800 \mu \mathrm{mol} \mathrm{L}^{-1}\right.$; C. Monnin, unpublished data). However, at the absence of porewater $\delta^{13} \mathrm{C}$-DIC data, we cannot fully determine the influence of porewater on the carbon uptake by primary producers.

Finally, porewater DIC should have isotope signature similar to the organic matter source deposited to sediments (Aller et al. 2008; Pozzato et al. 2018) and its carbon signatures are highly variable because of methanogenesis 
(LaZerte 1981). Decomposed macrophytes and particulate organic matter are the main components of organic matter in lagoon sediments (Garzon-Garcia et al. 2017), Because $\delta^{13} \mathrm{C}$ in macrophytes and particulate organic matter varies with salinity (Figure 6), the $\delta^{13} \mathrm{C}$-DIC in porewater is also likely to vary with salinity (thus a not-constant endmember), making it difficult to trace porewater $\delta^{13} \mathrm{C}$-DIC in the lagoon waters.

Whilst isotope data itself does not allow the differentiation of DIC contributions of groundwater and sewage input due to their similar signature, sewage contributions is commonly considered negligible in the carbon budget in coastal systems (unlike its role in the nitrogen budget) (Dudley and Shima 2010; Tseng et al. 2016). Therefore, overall, the carbon isotope data suggests that karstic groundwater, and seawater are the major sources of DIC in the studied lagoons.

\subsubsection{DIC uptake by primary producers}

Like for nitrogen, the DIC uptake by macrophytes occurs mainly through the leaves, and root contributions are considered insignificant (Hemminga and Mateo 1996; Enoch H. Z. and Olesen J. M. 2006). Primary producers sampled in this study are thus assumed to source also most of their inorganic carbon from the water column. Our results show overall low carbon signatures in primary producers located close to the karstic groundwater springs and high signatures from the marine parts, indicating different DIC sources (Figure 6). The low $\delta^{13} \mathrm{C}$ in macrophytes and phytoplankton (POM) sampled in the groundwater springs suggests that they incorporate groundwater-derived DIC, which is depleted in ${ }^{13} \mathrm{C}$ due to the mineralization of organic matter in the karstic springs (Figure 6).

Due to the smaller size of La Palme lagoon and relatively larger groundwater inflow and more restricted exchange with the ocean in comparison with Salses-Leucate lagoon, the relative impact of karstic groundwater is greater than in the larger, better-mixed Salses-Leucate lagoon (Stieglitz et al. 2013). The larger size of Salses-Leucate lagoon facilitates a more efficient lagoon water-atmosphere exchange due to larger wind fetch (Stieglitz et al. 2013). This is mirrored in the primary producers' carbon 
isotope signatures, indicating an overall greater assimilation of carbon of marine (atmospheric) origin in Salses-Leucate lagoon than in La Palme lagoon (Figure $6 \mathrm{~b}$ and $\mathrm{c}$ ).

DIC is considered a major control on the $\delta^{13} \mathrm{C}$ of the primary producers (Lin et al. 1991). $\delta^{13} \mathrm{C}$ in macrophytes and phytoplankton increase with increasing $\delta^{13} \mathrm{C}$-DIC in both lagoons (Figure 8), similar to previously reported relationships in coastal bay (Chanton and Lewis 1999) and lakes (LaZerte and Szalados 1982). However, a 1:1 relationship between the $\delta^{13} \mathrm{C}$-DIC and the $\delta^{13} \mathrm{C}$-primary producers is not observed. This is likely due to isotopic fractionation, although additional sources of carbon could also affect this relationship. Previous estimations of isotopic fractionation associated with inorganic carbon uptake are around 12\%o and 20\%o for macrophytes and phytoplankton, respectively (LaZerte and Szalados 1982; Chanton and Lewis 1999). These estimations are in good agreement with the fractionation factors derived in our study by applying the previously described approach (section 4.1.2) to carbon signatures along the salinity gradients $(16.7 \pm 5.4 \%$ o for macrophytes and $20.6 \pm 3.0 \%$ o for phytoplankton in La Palme lagoon; $14.8 \pm$ $6.0 \%$ or macrophytes and $20.3 \pm 3.3 \%$ for phytoplankton in Salses-Leucate lagoon). Fractionation thus explains the majority of the difference between the carbon signatures of DIC and primary producers and the lack of a 1:1 relationship. Assimilation of atmospheric $\mathrm{CO}_{2}$ during emersion as additional source of carbon for macrophytes can be excluded here because macrophytes are rarely to never exposed in the studied lagoons (tidal effects are negligible) (Hemminga \& Mateo, 1996).

The estimated fractionation factor during DIC uptake by concurrently analysing the $\delta^{13} \mathrm{C}$ in water and primary producers of the karstic groundwater spring is $21.3 \pm 3.4 \%$ for phytoplankton. Relatively constant carbon isotopic signatures are expected (and measured) in the groundwater spring, and thus we can assume that the $\delta^{13} \mathrm{C}$-DIC of the water column is representative of the signature taken up by the primary producers for this sample. A fractionation factor can also be estimated for the primary producers in the coastal Mediterranean Sea station (sea endmember), where $\delta^{13} \mathrm{C}$-DIC in water can also be assumed constant (unlike the rest of the lagoon). For the sea endmember, it 
is $24.5 \pm 2.1 \%$, which is slightly higher than in the groundwater endmember. This indicates that fractionation may be controlled by salinity, with fractionation being smaller at low salinities (groundwater) and greater at high salinity (sea), as previously reported by Chanton and Lewis (1999). This difference in fractionation may result from a change in phytoplankton species with salinity (e.g. Lionard et al. 2005). A quantitative estimation of groundwater versus porewater contributions on the DIC uptake by primary producers can not be made from the isotopic signature alone, but our indirect flux estimation (from water flow multiplied by endmember concentration) indicated contributions from both groundwater and porewater as sources of DIC to coastal lagoons.

\section{Conclusion}

This study provides direct evidence for the role of karstic groundwater and porewater fluxes in sustaining primary production in the studied coastal lagoons. The combined nitrogen isotopic signatures in macrophytes and phytoplankton demonstrate that karstic groundwater and porewater fluxes are the main sources of inorganic nitrogen assimilated by primary producers in La Palme and Salses-Leucate lagoons. Sewage effluents contribute, however, locally to the nitrogen input at times when sewage nitrogen concentrations are particularly high. Nitrogen isotope signatures in macrophytes represents longterm average source signatures while those of phytoplankton indicate recent variations in inputs.

The distinct signatures of carbon stable isotope in low-salinity karstic groundwater and seawater in the studied lagoons allowed us to differentiate between these two sources of dissolved inorganic carbon. The low carbon signatures from karstic groundwater were traced in primary producers collected in the low salinity parts of the lagoon, revealing the influence of groundwater inputs as a source of carbon to support primary production. Conversely, high signatures from the marine inorganic carbon were traced in primary producers located in the marine parts of the lagoons. 
Combination of nitrogen and carbon stable isotope signatures in both short-lived and long-lived primary producers allows tracing nitrogen and carbon sources from groundwater and advective porewater sustaining primary production in coastal ecosystems on the timescales of their lifespan.

The impact of karstic groundwater sustaining primary production is greater in the small La Palme lagoon due to larger fresh karstic groundwater inflow and the restricted exchange with the open sea. However, in the larger Salses-Leucate lagoon, the karstic groundwater influence is limited to the areas close to the sources. The hydrology of the two studied lagoons controls the ecological implications of the groundwater discharge as revealed by the isotope signatures.

\section{Acknowledgements}

We thank C Fleger \& K Fortune Sans (Parc Naturel Narbonnaise), L Fonbonne (Rivage Leucate), O Radakovitch (CEREGE), R de Wit (MARBEC Montpellier), A Fiandrino (IFREMER Sete), D Munaron (IFREMER Sete), V Bailly Comte (BRGM Montpellier) and $\mathrm{P}$ Cook (Flinders University) for sharing their expert knowledge on regional lagoon and groundwater processes, N Garcia (MIO Marseille) sample analysis, and C Monnin and J Tamborski (LEGOS Toulouse) for sharing carbon data from La Palme lagoon. The constructive comments from three reviewers are greatly appreciated. This research was funded by the French National Research Agency (ANR) through ANR @RAction chair medLOC (ANR-14-ACHN-0007-01 - project leader T Stieglitz), Labex OT-Med (ANR-11-LABEX-0061, part of the "Investissements d'Avenir" program through the A*MIDEX project ANR-11- IDEX-0001-02), and the European Union's Horizon 2020 research and innovation programme under the Marie Skłodowska-Curie grant agreement No 748896. 


\section{FIGURES}

Figure 1
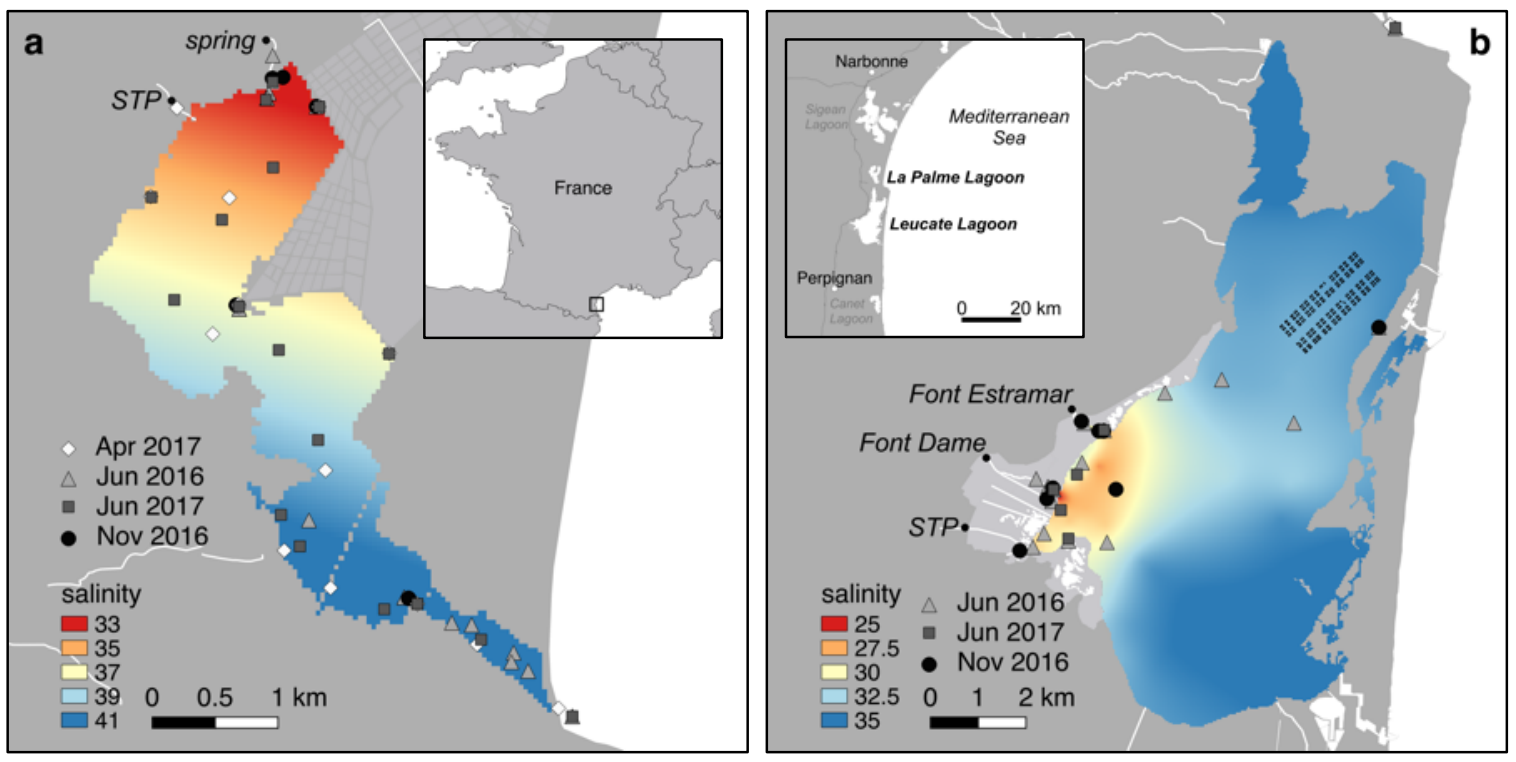

Figure 1: Sampling locations overlaid on the surface salinity distribution (June 2016) in La Palme (a) and Salses-Leucate (b) lagoons (modified from Rodellas et al 2018). Locations of sewage treatment plants (STP) and groundwater springs are shown. 


\section{Figure 2}
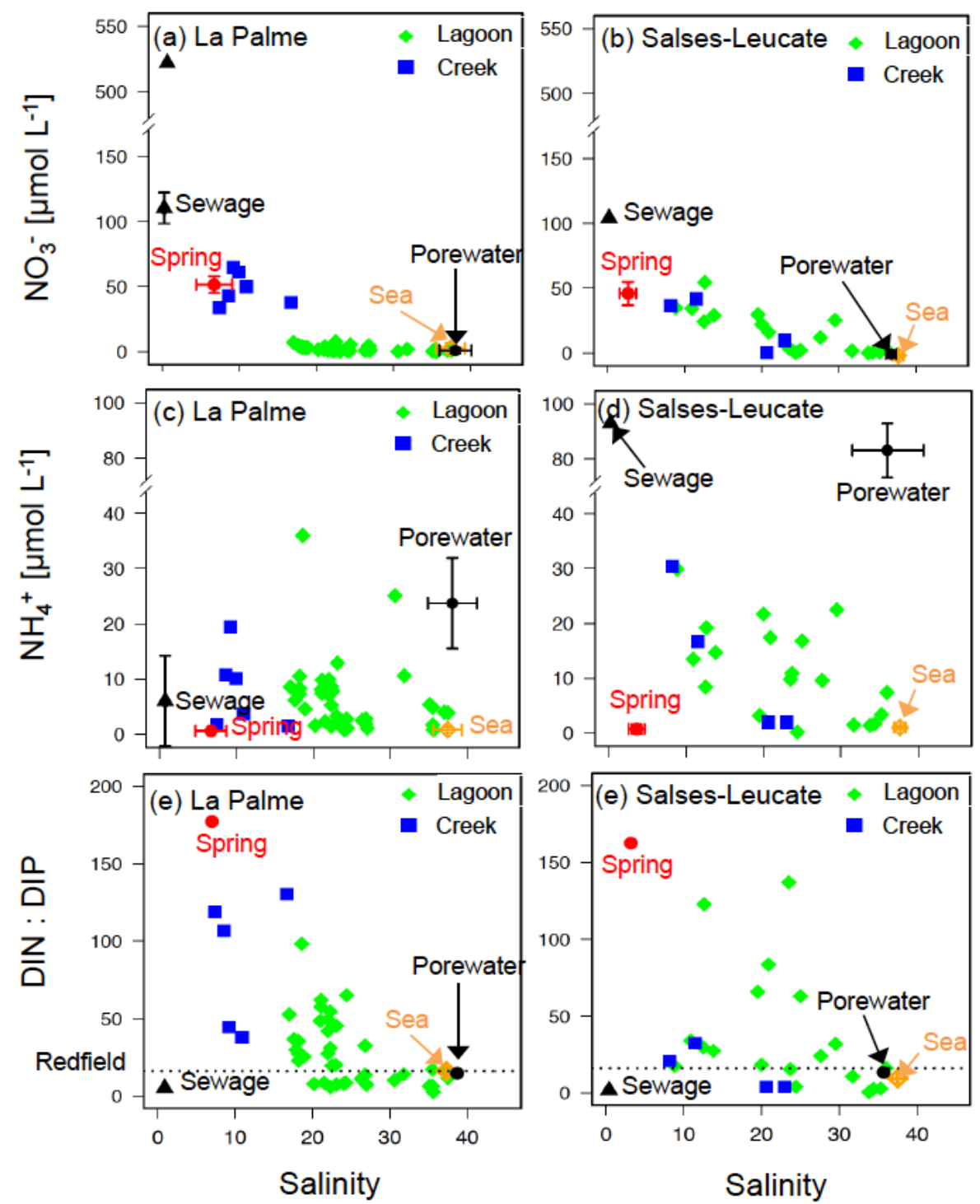

Figure 2: Variation of $\mathrm{NO}_{3}^{-}(\mathrm{a}, \mathrm{b}), \mathrm{NH}_{4}{ }^{+}$(c, d) concentrations and the stoichiometric ratios of DIN:DIP (e, f) along the salinity gradient in La Palme and Salses-Leucate lagoons, respectively. The dashed lines represent the DIN:DIP Redfield ratio of 16:1. Endmembers indicate the average $\mathrm{NO}_{3}{ }^{-}$and $\mathrm{NH}_{4}{ }^{+}$concentrations and the DIN:DIP ratios in the sewage effluents (black triangle), springs (red circle) and seawater (orange diamond). $\mathrm{NO}_{3}{ }^{-}$and $\mathrm{NH}_{4}{ }^{+}$ concentrations and DIN:DIP data in the lagoons (green diamond) and the creeks (blue square) are not differentiated for the four sampling campaigns. Note the scale differences on the y-axes and the axis breaks. 


\section{Figure 3}

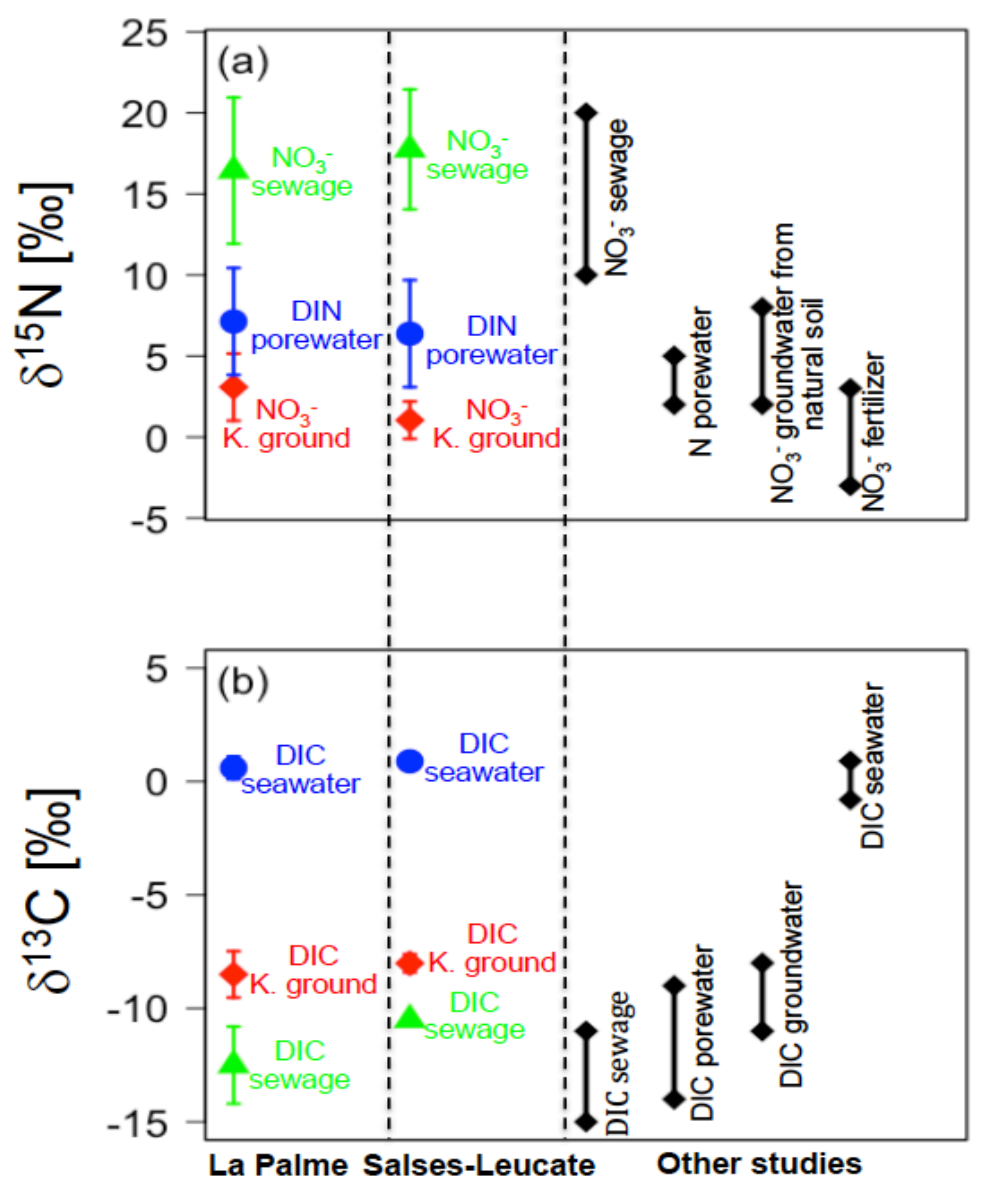

Figure 3: (a) The $\delta^{15} \mathrm{~N}$ of nitrogen $\left(\delta^{15} \mathrm{~N}-\mathrm{NO}_{3}-\right.$ for sewage and groundwater samples; $\delta^{15} \mathrm{~N}$-DIN for porewater samples) and (b) the $\delta^{13} \mathrm{C}$ of DIC sources measured in La Palme and Salses-Leucate lagoons compared with nitrogen sources in literature. The isotopic signatures of the nitrogen sources (sewage, porewater and springs) and carbon sources (sewage, groundwater and seawater in equilibrium with the atmospheric $\mathrm{CO}_{2}$ ) measured in this study are in good agreement with values reported in the literature (Atekwana and Krishnamurthy 1998; Chanton and Lewis 1999; Cole et al. 2005; Kendall et al. 2007; Yang et al. 2008; Barros et al. 2010). 


\section{Figure 4}
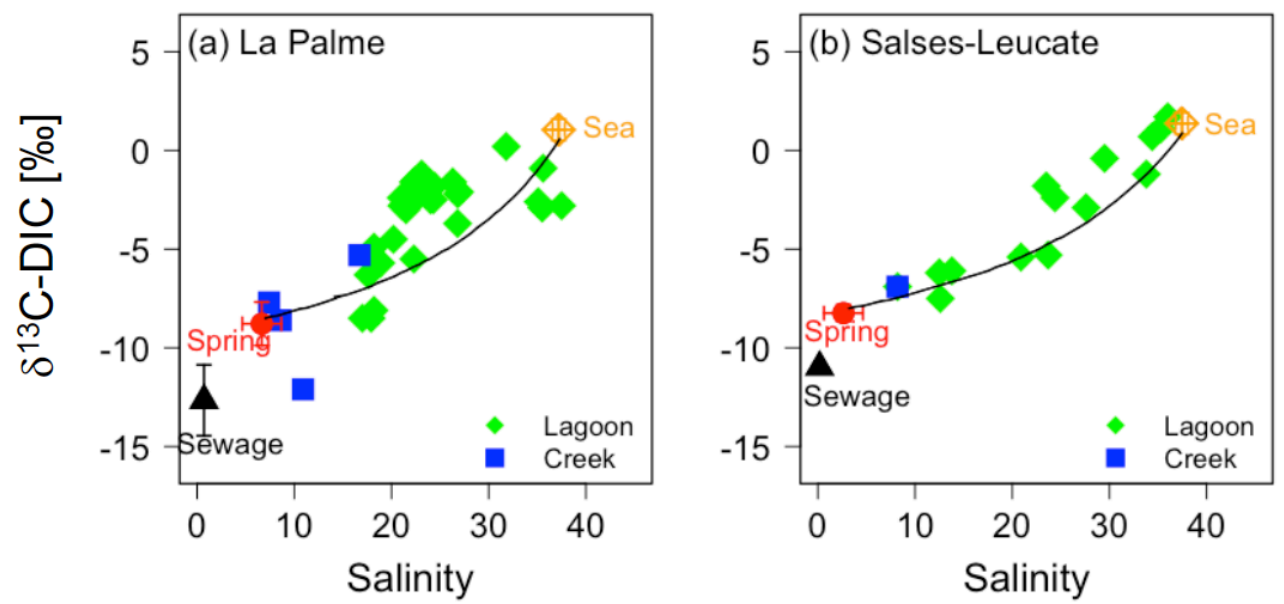

Figure 4: $\delta^{13} \mathrm{C}$ of DIC in water along the salinity gradient in La Palme (a) and Salses-Leucate (b) lagoons. Endmembers indicate the average $\delta^{13} \mathrm{C}$-DIC in the sewage effluents (black triangle), springs (red circle) and seawater (orange diamond). $\delta^{13}$ C-DIC samples are not differentiated for the four sampling campaigns. The black lines represent the conservative binary isotopic mixing line between $\delta^{13} \mathrm{C}$-DIC in karstic groundwater and seawater endmembers, derived using the DIC concentrations in groundwater (5900 $\left.\pm 800 \mu \mathrm{mol} \mathrm{L}^{-1}\right)$ and in seawater $\left(2300 \pm 200 \mu \mathrm{mol} \mathrm{L}^{-1}\right)$ (C. Monnin, pers. comm.) (Chanton and Lewis 1999). 


\section{Figure 5}
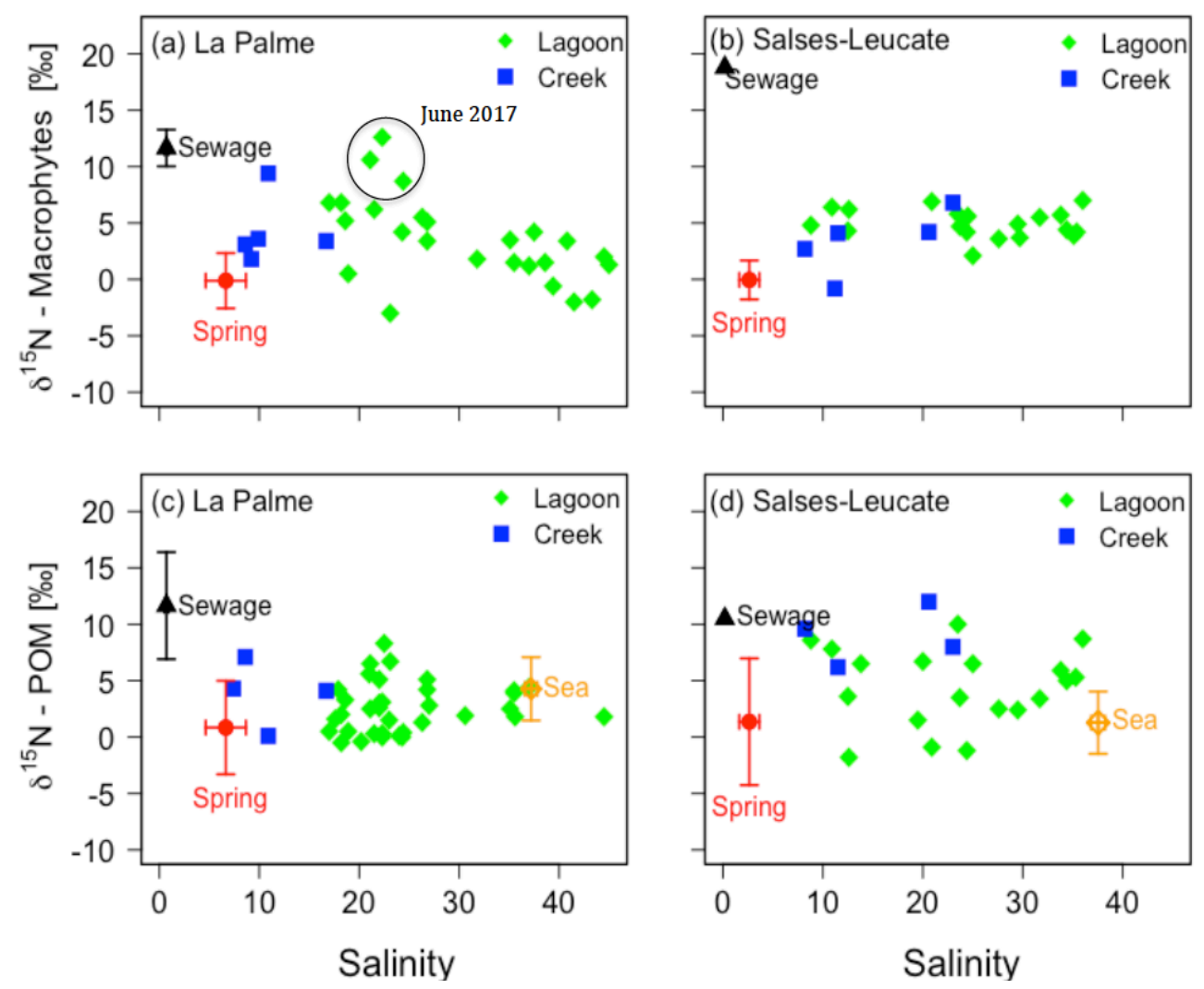

Figure 5: The $\delta^{15} \mathrm{~N}$ of macrophytes (a, b) and POM (c, d) along the salinity gradient in La Palme and Salses-Leucate lagoons, respectively. Endmembers indicate the average $\delta^{15} \mathrm{~N}$ of primary producers sampled close to the sewage outlet (black triangle), springs (red circle) and seawater (orange diamond). The $\delta^{15} \mathrm{~N}$ data from primary producers are shown together for the four sampling campaigns. 


\section{Figure 6}
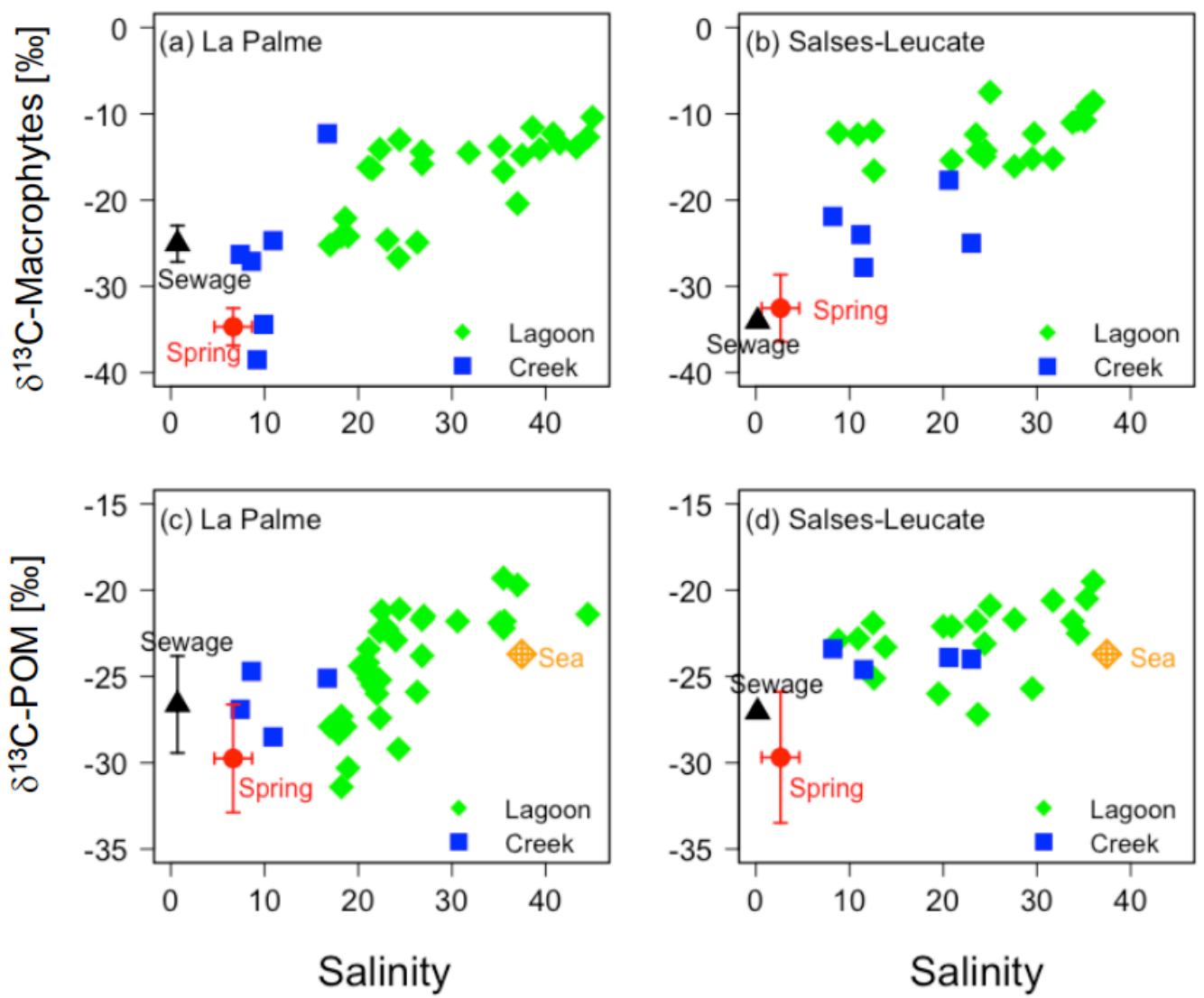

Figure 6: The $\delta^{13} \mathrm{C}$ of macrophytes $(\mathrm{a}, \mathrm{b})$ and POM (c, d) along the salinity gradient in La Palme and Salses-Leucate lagoons, respectively. Endmembers indicate the average $\delta^{13} \mathrm{C}$ of primary producers in the sewage effluents (black triangle), springs (red circle) and seawater (orange diamond). The shown $\delta^{13} \mathrm{C}$ data from primary producers are shown together for the four sampling campaigns. Note the scale difference for the y-axes. 


\section{Figure 7}
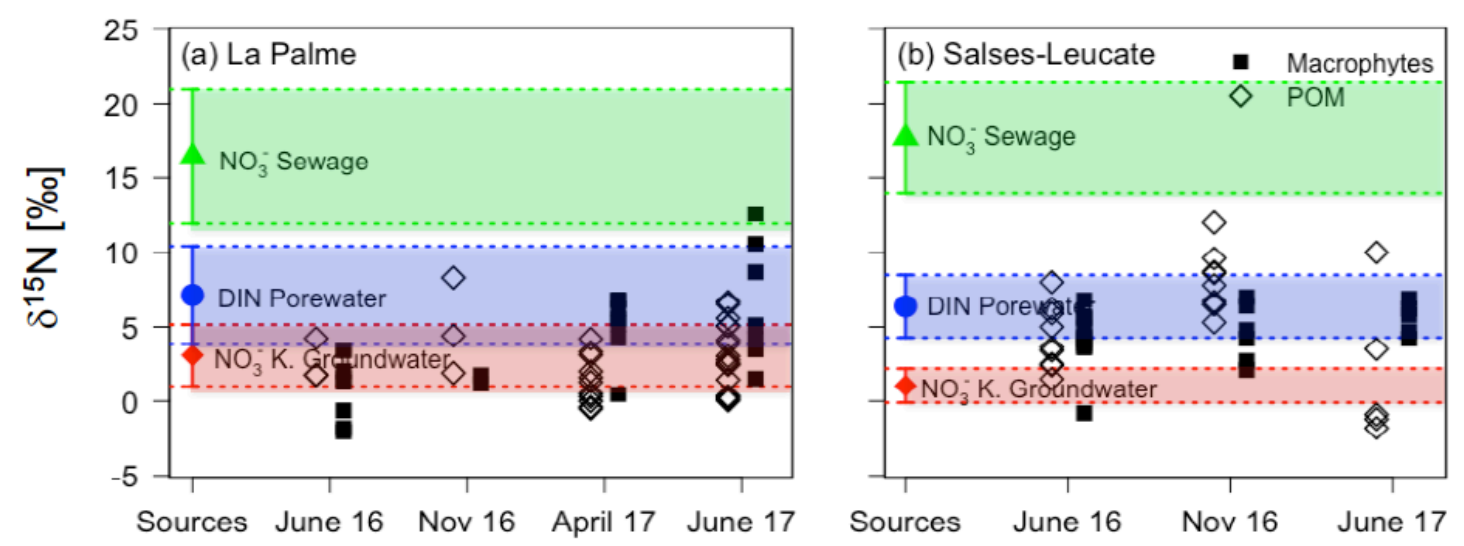

Figure 7: The $\delta^{15} \mathrm{~N}$ of macrophytes and POM (phytoplankton) in La Palme (a) and Salses-Leucate (b) lagoons, together with the isotopic signatures measured in inorganic nitrogen dissolved in water from the three identified sources. The nitrogen isotopic signatures are measured values and thus are not corrected for fractionation. 


\section{Figure 8}
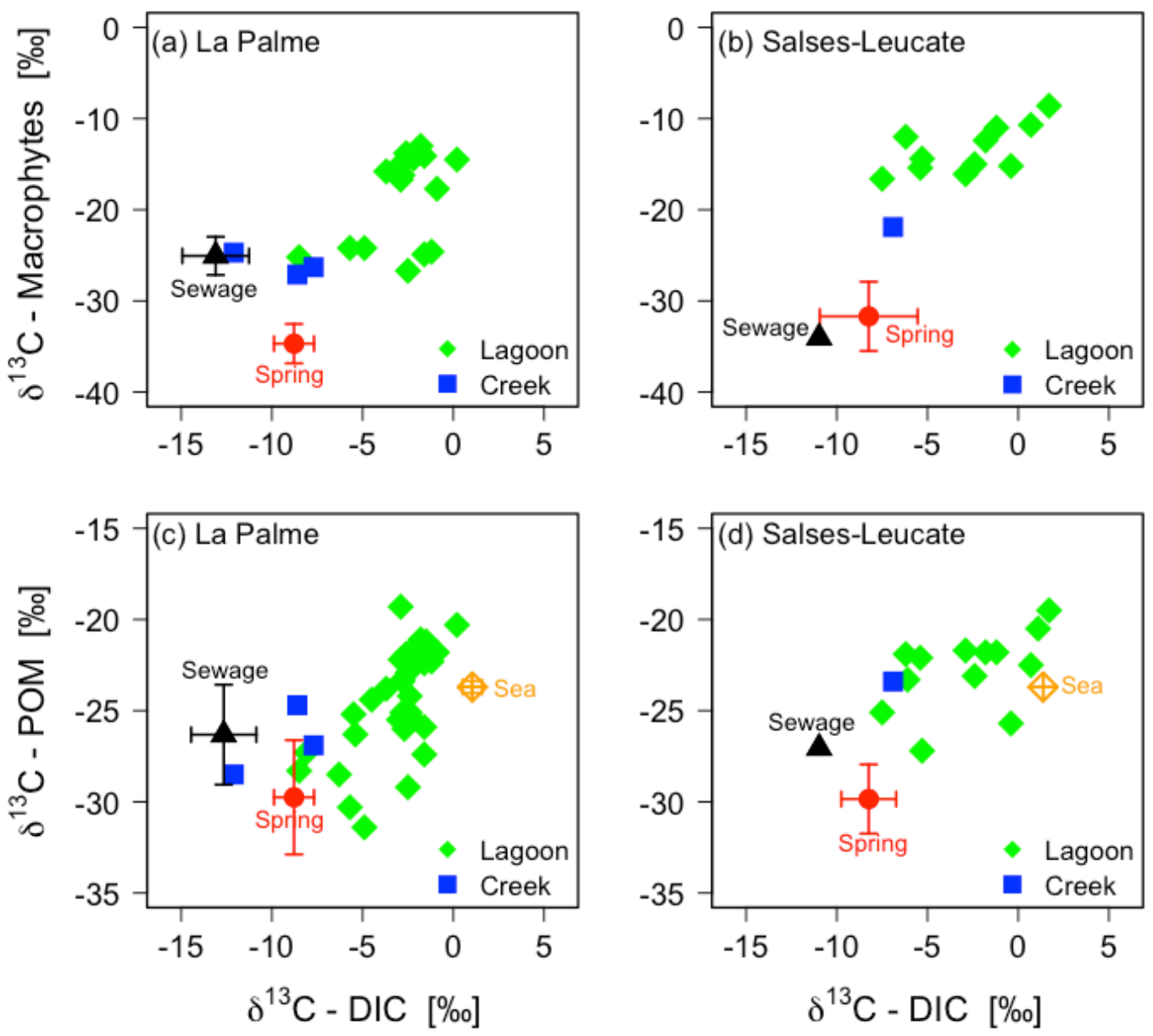

Figure 8: The $\delta^{13} \mathrm{C}$ of Macrophytes $(\mathrm{a}, \mathrm{b})$ and POM (c, d) versus $\delta^{13} \mathrm{C}$-DIC in lagoon water from La Palme and Salses-Leucate lagoons, respectively. Endmembers indicate the average $\delta^{13} \mathrm{C}$ of primary producers in the sewage effluents (black triangle), springs (red circle) and seawater (orange diamond). $\delta^{13} \mathrm{C}$ data from primary producers in the lagoons (green diamond) and the creeks (blue square) are shown together for the four sampling campaigns. Note the scale difference on the y-axes. 


\section{References}

Aller, R. C., N. E. Blair, and G. J. Brunskill. 2008. Early diagenetic cycling, incineration, and burial of sedimentary organic carbon in the central Gulf of Papua (Papua New Guinea). J. Geophys. Res. Earth Surf. 113: F01S09. doi:10.1029/2006JF000689

Altabet, M. A., and R. Francois. 1994. Sedimentary nitrogen isotopic ratio as a recorder for surface ocean nitrate utilization. Glob. Biogeochem. Cycles 8: 103-116. doi:10.1029/93GB03396

Aminot, A., and R. Kérouel. 2007. Dosage automatique des nutriments dans les eaux marines: méthodes en flux continu, Editions Quae.

An, S., and W. S. Gardner. 2002. Dissimilatory nitrate reduction to ammonium (DNRA) as a nitrogen link, versus denitrification as a sink in a shallow estuary (Laguna Madre/Baffin Bay, Texas). Mar. Ecol. Prog. Ser. 237: 41-50.

Anschutz, P., C. Charbonnier, J. Deborde, L. Deirmendjian, D. Poirier, A. Mouret, D. Buquet, and P. Lecroart. 2016. Terrestrial groundwater and nutrient discharge along the 240-km-long Aquitanian coast. Mar. Chem. 185: 38-47. doi:10.1016/j.marchem.2016.04.002

Aravena, R., M. L. Evans, and J. A. Cherry. 1993. Stable Isotopes of Oxygen and Nitrogen in Source Identification of Nitrate from Septic Systems. Ground Water 31: 180-186. doi:10.1111/j.1745-6584.1993.tb01809.x

Arnaud, P. 1968. Les salinités de l'étang de Salses-Leucate et le régime des eaux souterraines. Rev. Trav. Inst. Pêch. Marit. 31: 109-116.

Atekwana, E. A., and D. K. Krishnamurthy. 1998. Seasonal Varia-tions of Dissolved Inorganic Carbon and A130 of Surface Waters: Application of a Modified Gas Evolution Technique. J. Hydrol. 205z265-278.

Atkins, M. L., I. R. Santos, S. Ruiz-Halpern, and D. T. Maher. 2013. Carbon dioxide dynamics driven by groundwater discharge in a coastal floodplain creek. J. Hydrol. 493: 30-42. doi:10.1016/j.jhydrol.2013.04.008

Barros, G. V., L. A. Martinelli, T. M. Oliveira Novais, J. P. H. B. Ometto, and G. M. Zuppi. 2010. Stable isotopes of bulk organic matter to trace carbon and nitrogen dynamics in an estuarine ecosystem in Babitonga Bay (Santa Catarina, Brazil). Sci. Total Environ. 408: 2226-2232. doi:10.1016/j.scitotenv.2010.01.060

Benson, E. R., J. M. O’Neil, and W. C. Dennison. 2008. Using the aquatic macrophyte Vallisneria americana (wild celery) as a nutrient bioindicator. Hydrobiologia 596: 187-196. doi:10.1007/s10750-0079095-0

Boschker, H. T. S., J. C. Kromkamp, and J. J. Middelburg. 2005. Biomarker and carbon isotopic constraints on bacterial and algal community structure and functioning in a turbid, tidal estuary. Limnol. Oceanogr. 50: 70-80. 
Brabandere, L. D., T. K. Frazer, and J. P. Montoya. 2007. Stable nitrogen isotope ratios of macrophytes and associated periphyton along a nitrate gradient in two subtropical, spring-fed streams. Freshw. Biol. 52: 15641575. doi:10.1111/j.1365-2427.2007.01788.x

Bradley, P. B., M. P. Sanderson, M. E. Frischer, J. Brofft, M. G. Booth, L. J. Kerkhof, and D. A. Bronk. 2010. Inorganic and organic nitrogen uptake by phytoplankton and heterotrophic bacteria in the stratified Mid-Atlantic Bight. Estuar. Coast. Shelf Sci. 88: 429-441. doi:10.1016/j.ecss.2010.02.001

Brunet, F., D. Gaiero, J. L. Probst, P. J. Depetris, F. Gauthier Lafaye, and P. Stille. 2005. $\delta^{13} \mathrm{C}$ tracing of dissolved inorganic carbon sources in Patagonian rivers (Argentina). Hydrol. Process. 19: 3321-3344. doi:10.1002/hyp.5973

Burnett, W. C., H. Bokuniewicz, M. Huettel, W. S. Moore, and M. Taniguchi. 2003. Groundwater and Pore Water Inputs to the Coastal Zone. Biogeochemistry 66: 3-33.

Cai, W.-J., Y. Wang, J. Krest, and W. S. Moore. 2003. The geochemistry of dissolved inorganic carbon in a surficial groundwater aquifer in North Inlet, South Carolina, and the carbon fluxes to the coastal ocean. Geochim. Cosmochim. Acta 67: 631-639. doi:10.1016/S00167037(02)01167-5

Capone, D. G. 2008. Nitrogen in the marine environment, Elsevier.

Carlier, A., P. Riera, J. Amouroux, J. Bodiou, M. Desmalades, and A. Grémare. 2009. Spatial heterogeneity in the food web of a heavily modified Mediterranean coastal lagoon: stable isotope evidence. Aquat. Biol. 5: 167-179. doi:10.3354/ab00147

Carlier, A., P. Riera, J.-M. Amouroux, J.-Y. Bodiou, K. Escoubeyrou, M. Desmalades, J. Caparros, and A. Grémare. 2007. A seasonal survey of the food web in the Lapalme Lagoon (northwestern Mediterranean) assessed by carbon and nitrogen stable isotope analysis. Estuar. Coast. Shelf Sci. 73: 299-315. doi:10.1016/j.ecss.2007.01.012

Chanton, J. P., and F. G. Lewis. 1999. Plankton and Dissolved Inorganic Carbon Isotopic Composition in a River-Dominated Estuary: Apalachicola Bay, Florida. Estuaries 22: 575. doi:10.2307/1353045

Chappuis Eglantine, Seriñá Vanesa, Martí Eugènia, Ballesteros Enric, and Gacia Esperança. 2017. Decrypting stable - isotope $(\delta 13 \mathrm{C}$ and $\delta 15 \mathrm{~N})$ variability in aquatic plants. Freshw. Biol. 62: 1807-1818. doi:10.1111/fwb.12996

Christensen, P. B., S. Rysgaard, N. P. Sloth, T. Dalsgaard, and S. Schw $\backslash$ a erter. 2000. Sediment mineralization, nutrient fluxes, denitrification and dissimilatory nitrate reduction to ammonium in an estuarine fjord with sea cage trout farms. Aquat. Microb. Ecol. 21: 73-84. 
Cloern, J. E., E. A. Canuel, and D. Harris. 2002. Stable carbon and nitrogen isotope composition of aquatic and terrestrial plants of the San Francisco Bay estuarine system. Limnol. Oceanogr. 47: 713-729.

Cohen, R. A., and A. M. Bradham. 2010. Uptake of stable N isotopes by Myriophyllum spicatum is not selective. Aquat. Bot. 92: 227-232. doi:10.1016/j.aquabot.2009.12.005

Cohen, R. A., and P. Fong. 2005. EXPERIMENTAL EVIDENCE SUPPORTS THE USE OF $\delta 15 \mathrm{~N}$ CONTENT OF THE OPPORTUNISTIC GREEN MACROALGA ENTEROMORPHA INTESTINALIS (CHLOROPHYTA) TO DETERMINE NITROGEN SOURCES TO ESTUARIES1: MACROALGAL N ISOTOPIC FRACTIONATION. J. Phycol. 41: 287-293. doi:10.1111/j.15298817.2005.04022.x

Cole, M. L., K. D. Kroeger, J. W. McClelland, and I. Valiela. 2005. Macrophytes as indicators of land-derived wastewater: Application of a $\delta^{15} \mathrm{~N}$ method in aquatic systems: MACROPHYTES AS INDICATORS OF WASTEWATER. Water Resour. Res. 41: n/a-n/a. doi:10.1029/2004WR003269

Cole, M. L., K. D. Kroeger, J. W. Mcclelland, and I. Valiela. 2006. Effects of Watershed Land use on Nitrogen Concentrations and $\delta 15$ Nitrogen in Groundwater. Biogeochemistry 77: 199-215. doi:10.1007/s10533005-1036-2

Cook, P. G., V. Rodellas, A. Andrisoa, and T. C. Stieglitz. 2018. Exchange across the sediment-water interface quantified from porewater radon profiles. J. Hydrol. 559: 873-883. doi:10.1016/j.jhydrol.2018.02.070

Cyronak, T., I. R. Santos, D. V. Erler, and B. D. Eyre. 2013. Groundwater and porewater as major sources of alkalinity to a fringing coral reef lagoon (Muri Lagoon, Cook Islands). Biogeosciences 10: 2467-2480. doi:10.5194/bg-10-2467-2013

Das Gupta, A., S. Sarkar, J. Singh, T. Saha, and A. K. Sil. 2016. Nitrogen dynamics of the aquatic system is an important driving force for efficient sewage purification in single pond natural treatment wetlands at East Kolkata Wetland. Chemosphere 164: 576-584. doi:10.1016/j.chemosphere.2016.08.140

Deborde, J., P. Anschutz, I. Auby, C. Glé, M.-V. Commarieu, D. Maurer, P. Lecroart, and G. Abril. 2008. Role of tidal pumping on nutrient cycling in a temperate lagoon (Arcachon Bay, France). Mar. Chem. 109: 98-114. doi:10.1016/j.marchem.2007.12.007

Derolez, V., J. Oheix, V. Ouisse, and others. 2015. Suivi estival des lagunes méditerranéennes françaises-Bilan des résultats 2014.

Derse, E., K. L. Knee, S. D. Wankel, C. Kendall, C. J. Berg, and A. Paytan. 2007. Identifying Sources of Nitrogen to Hanalei Bay, Kauai, Utilizing the Nitrogen Isotope Signature of Macroalgae. Environ. Sci. Technol. 41: 5217-5223. doi:10.1021/es0700449 
Dorsett, A., J. Cherrier, J. B. Martin, and J. E. Cable. 2011. Assessing hydrologic and biogeochemical controls on pore-water dissolved inorganic carbon cycling in a subterranean estuary: A 14C and 13C mass balance approach. Mar. Chem. 127: 76-89. doi:10.1016/j.marchem.2011.07.007

Dudley, B. D., and J. S. Shima. 2010. Algal and invertebrate bioindicators detect sewage effluent along the coast of Titahi Bay, Wellington, New Zealand. N. Z. J. Mar. Freshw. Res. 44: 39-51. doi:10.1080/00288331003641687

Enoch H. Z., and Olesen J. M. 2006. Plant response to irrigation with water enriched with carbon dioxide. New Phytol. 125: 249-258. doi:10.1111/j.1469-8137.1993.tb03880.x

Evans, R. D. 2001. Physiological mechanisms influencing plant nitrogen isotope composition. Trends Plant Sci. 6: 121-126. doi:10.1016/S13601385(01)01889-1

Fleury, P., M. Bakalowicz, and G. de Marsily. 2007. Submarine springs and coastal karst aquifers: A review. J. Hydrol. 339: 79-92. doi:10.1016/j.jhydrol.2007.03.009

Fry, B. 2003. Steady state models of stable isotopic distributions. Isotopes Environ. Health Stud. 39: 219-232. doi:10.1080/1025601031000108651

Garzon-Garcia, A., J. P. Laceby, J. M. Olley, and S. E. Bunn. 2017. Differentiating the sources of fine sediment, organic matter and nitrogen in a subtropical Australian catchment. Sci. Total Environ. 575: 1384-1394. doi:10.1016/j.scitotenv.2016.09.219

Gillikin, D. P., A. Lorrain, S. Bouillon, P. Willenz, and F. Dehairs. 2006. Stable carbon isotopic composition of Mytilus edulis shells: relation to metabolism, salinity, $\delta 13 \mathrm{CDIC}$ and phytoplankton. Org. Geochem. 37: 1371-1382. doi:10.1016/j.orggeochem.2006.03.008

Hansen, J., M. Sato, R. Ruedy, K. Lo, D. W. Lea, and M. Medina-Elizade. 2006. Global temperature change. Proc. Natl. Acad. Sci. 103: 14288-14293. doi:10.1073/pnas.0606291103

Hansen, J. W., J. W. Udy, C. J. Perry, W. C. Dennison, and B. A. Lomstein. 2000. Effect of the seagrass Zostera capricorni on sediment microbial processes. Mar. Ecol. Prog. Ser. 83-96.

Hellings, L., F. Dehairs, S. Van Damme, and W. Baeyens. 2001. Dissolved inorganic carbon in a highly polluted estuary (the Scheldt). Limnol. Oceanogr. 46: 1406-1414. doi:10.4319/lo.2001.46.6.1406

Hemminga, M. A., N. Marba, and J. Stapel. 1999. Leaf nutrient resorption, leaf lifespan and the retention of nutrients in seagrass systems. Aquat. Bot. 65: 141-158.

Hemminga, M., and M. Mateo. 1996. Stable carbon isotopes in seagrasses:variability in ratios and use in ecological studies. Mar. Ecol. Prog. Ser. 140: 285-298. doi:10.3354/meps140285 
Herrera-Silveira, J. A. 1998. Nutrient-phytoplankton production relationships in a groundwater-influenced tropical coastal lagoon. Aquat. Ecosyst. Health Manag. 1: 373-385.

Holmes, R. M., A. Aminot, R. Kérouel, B. A. Hooker, and B. J. Peterson. 1999. A simple and precise method for measuring ammonium in marine and freshwater ecosystems. Can. J. Fish. Aquat. Sci. 56: 1801-1808.

Holmes, R. M., J. W. McClelland, D. M. Sigman, B. Fry, and B. J. Peterson. 1998. Measuring $15 \mathrm{~N}-\mathrm{NH} 4+$ in marine, estuarine and fresh waters: An adaptation of the ammonia diffusion method for samples with low ammonium concentrations. Mar. Chem. 60: 235-243.

Hwang, D.-W., G. Kim, Y.-W. Lee, and H.-S. Yang. 2005. Estimating submarine inputs of groundwater and nutrients to a coastal bay using radium isotopes. Mar. Chem. 96: 61-71. doi:10.1016/j.marchem.2004.11.002

Ifremer. 2014. Réseau de Suivi Lagunaire du Languedoc-Roussillon. Bilan des résultats 2013.

Inglett, P. W., and K. R. Reddy. 2006. Investigating the use of macrophyte stable $\mathrm{C}$ and $\mathrm{N}$ isotopic ratios as indicators of wetland eutrophication: Patterns in the P-affected Everglades. Limnol. Oceanogr. 51: 23802387. doi:10.4319/lo.2006.51.5.2380

Kendall, C. 2015. Resources on Isotopes. Delta 16: 6.

Kendall, C., and R. Aravena. 2000. Nitrate Isotopes in Groundwater Systems, p. 261-297. In Environmental Tracers in Subsurface Hydrology. Springer, Boston, MA.

Kendall, C., E. M. Elliott, and S. D. Wankel. 2007. Tracing anthropogenic inputs of nitrogen to ecosystems. Stable Isot. Ecol. Environ. Sci. 2: 375-449.

Kim, H., K. Lee, D.-I. Lim, and others. 2017. Widespread Anthropogenic Nitrogen in Northwestern Pacific Ocean Sediment. Environ. Sci. Technol. 51: 6044-6052. doi:10.1021/acs.est.6b05316

Kirkwood, D. S. 1992. Stability of solutions of nutrient salts during storage. Mar. Chem. 38: 151-164.

Knee, K. L., J. H. Street, E. E. Grossman>, A. B. Boehm, and A. Paytan. 2010. Nutrient inputs to the coastal ocean from submarine groundwater discharge in a groundwater-dominated system: Relation to land use (Kona coast, Hawaii, U.S.A.). Limnol. Oceanogr. 55: 1105-1122. doi:10.4319/lo.2010.55.3.1105

Kohzu, A., T. Miyajima, I. Tayasu, and others. 2008. Use of Stable Nitrogen Isotope Signatures of Riparian Macrophytes As an Indicator of Anthropogenic N Inputs to River Ecosystems. Environ. Sci. Technol. 42: 7837-7841. doi:10.1021/es801113k

Kroeger, K. D., P. W. Swarzenski, W. J. Greenwood, and C. Reich. 2007. Submarine groundwater discharge to Tampa Bay: Nutrient fluxes and biogeochemistry of the coastal aquifer. Mar. Chem. 104: 85-97. doi:10.1016/j.marchem.2006.10.012 
Lacoste, é, P. Raimbault, M. Harmelin-Vivien, and N. Gaertner-Mazouni. 2016. Trophic relationships between the farmed pearl oyster Pinctada margaritifera and its epibionts revealed by stable isotopes and feeding experiments. Aquac. Environ. Interact. 8: 55-66. doi:10.3354/aei00157

Lassauque, J., G. Lepoint, T. Thibaut, P. Francour, and A. Meinesz. 2010. Tracing sewage and natural freshwater input in a Northwest Mediterranean bay: Evidence obtained from isotopic ratios in marine organisms. Mar. Pollut. Bull. 60: 843-851. doi:10.1016/j.marpolbul.2010.01.008

LaZerte, B. D. 1981. The relationship between total dissolved carbon dioxide and its stable carbon isotope ratio in aquatic sediments. Geochim. Cosmochim. Acta 45: 647-656. doi:10.1016/0016-7037(81)90039-9

LaZerte, B. D., and J. E. Szalados. 1982. Stable carbon isotope ratio of submerged freshwater macrophytes1,1: Carbon ratio of macrophytes. Limnol. Oceanogr. 27: 413-418. doi:10.4319/lo.1982.27.3.0413

Lee, K.-S., and K. H. Dunton. 1999. Inorganic nitrogen acquisition in the seagrass Thalassia testudinum: Development of a whole-plant nitrogen budget. Limnol. Oceanogr. 44: 1204-1215.

Leffler, A. J., and J. M. Welker. 2013. Long-term increases in snow pack elevate leaf $\mathrm{N}$ and photosynthesis in Salix arctica : responses to a snow fence experiment in the High Arctic of NW Greenland. Environ. Res. Lett. 8: 025023. doi:10.1088/1748-9326/8/2/025023

Lepoint, G., P. Dauby, and S. Gobert. 2004. Applications of C and N stable isotopes to ecological and environmental studies in seagrass ecosystems. Mar. Pollut. Bull. 49: 887-891. doi:10.1016/j.marpolbul.2004.07.005

Lepoint, G., F. Nyssen, S. Gobert, P. Dauby, and J.-M. Bouquegneau. 2000. Relative impact of a seagrass bed and its adjacent epilithic algal community in consumer diets. Mar. Biol. 136: 513-518. doi:10.1007/s002270050711

Li, S.-L., C.-Q. Liu, J. Li, Y.-C. Lang, H. Ding, and L. Li. 2010. Geochemistry of dissolved inorganic carbon and carbonate weathering in a small typical karstic catchment of Southwest China: Isotopic and chemical constraints. Chem. Geol. 277: 301-309. doi:10.1016/j.chemgeo.2010.08.013

Lin, G., T. Banks, and L. da S. L. O. R. Sternberg. 1991. Variation in $\delta 13 \mathrm{C}$ values for the seagrass Thalassia testudinum and its relations to mangrove carbon. Aquat. Bot. 40: 333-341. doi:10.1016/0304-3770(91)90079-K

Lionard, M., K. Muylaert, D. V. Gansbeke, and W. Vyverman. 2005. Influence of changes in salinity and light intensity on growth of phytoplankton communities from the Schelde river and estuary (Belgium/The Netherlands). Hydrobiologia 540: 105-115. doi:10.1007/s10750-0047123-x 
Liu, X., Z. Yu, X. Song, and X. Cao. 2009. The nitrogen isotopic composition of dissolved nitrate in the Yangtze River (Changjiang) estuary, China. Estuar. Coast. Shelf Sci. 85: 641-650. doi:10.1016/j.ecss.2009.09.017

Lotze, H. K., and W. Schramm. 2000. Ecophysiological traits explain species dominance patterns in macroalgal blooms. J. Phycol. 36: 287-295. doi:10.1046/j.1529-8817.2000.99109.x

Marbà, N., M. A. Hemminga, and C. M. Duarte. 2006. Resource translocation within seagrass clones: allometric scaling to plant size and productivity. Oecologia 150: 362-372. doi:10.1007/s00442-006-0524-y

McClelland, J. W., and I. Valiela. 1998. Linking nitrogen in estuarine producers to land-derived sources. Limnol. Oceanogr. 43: 577-585. doi:10.4319/lo.1998.43.4.0577

McGlathery, K. J., N. Risgaard-Petersen, and P. B. Christensen. 1998. Temporal and spatial variation in nitrogen fixation activity in the eelgrass Zostera marina rhizosphere. Mar. Ecol. Prog. Ser. 245-258.

Middelburg, J. ., and J. Nieuwenhuize. 2001. Nitrogen Isotope Tracing of Dissolved Inorganic Nitrogen Behaviour in Tidal Estuaries. Estuar. Coast. Shelf Sci. 53: 385-391. doi:10.1006/ecss.2001.0805

Middelburg, J. J., and J. Nieuwenhuize. 2000. Uptake of dissolved inorganic nitrogen in turbid, tidal estuaries. Mar. Ecol. Prog. Ser. 192: 79-88.

Miyajima, T., Y. Miyajima, Y. T. Hanba, K. Yoshii, T. Koitabashi, and E. Wada. 1995. Determining the stable isotope ratio of total dissolved inorganic carbon in lake water by GC/C/IIRMS. Limnol. Oceanogr. 40: 994-1000. doi:10.4319/lo.1995.40.5.0994

Montoya, J. P., and J. J. McCarthy. 1995. Isotopic fractionation during nitrate uptake by phytoplankton grown in continuous culture. J. Plankton Res. 17: 439-464. doi:10.1093/plankt/17.3.439

Moore, W. S. 2010. The Effect of Submarine Groundwater Discharge on the Ocean. Annu. Rev. Mar. Sci. 2: 59-88. doi:10.1146/annurev-marine120308-081019

Niencheski, L. F. H., H. L. Windom, W. S. Moore, and R. A. Jahnke. 2007. Submarine groundwater discharge of nutrients to the ocean along a coastal lagoon barrier, Southern Brazil. Mar. Chem. 106: 546-561. doi:10.1016/j.marchem.2007.06.004

Pasqueron De Fommervault, O., F. D’Ortenzio, A. Mangin, and others. 2015. Seasonal variability of nutrient concentrations in the Mediterranean Sea: Contribution of Bio-Argo floats. J. Geophys. Res. Oceans 120: 85288550. doi:10.1002/2015JC011103

Patriquin, D., and R. Knowles. 1972. Nitrogen fixation in the rhizosphere of marine angiosperms. Mar. Biol. 16: 49-58.

Phillips, D. L., and J. W. Gregg. 2003. Source partitioning using stable isotopes: coping with too many sources. Oecologia 136: 261-269. doi:10.1007/s00442-003-1218-3 
PNRNM. 2016. Observatoire des étangs. Parc Nat. Régional Narbonnaise En Méditerranée.

Pozzato, L., J. Rassmann, B. Lansard, J.-P. Dumoulin, P. van Breugel, and C. Rabouille. 2018. Origin of remineralized organic matter in sediments from the Rhone River prodelta (NW Mediterranean) traced by $\triangle 14 \mathrm{C}$ and $\delta 13 \mathrm{C}$ signatures of pore water DIC. Prog. Oceanogr. 163: 112-122. doi:10.1016/j.pocean.2017.05.008

Raimbault, P., N. Garcia, and F. Cerutti. 2008. Distribution of inorganic and organic nutrients in the South Pacific Ocean- evidence for long-term accumulation of organic matter in nitrogen-depleted waters. Biogeosciences 5: 281-298.

Raimbault, P., G. Slawyk, B. Boudjellal, and others. 1999. Carbon and nitrogen uptake and export in the equatorial Pacific at $150^{\circ} \mathrm{W}$ : Evidence of an efficient regenerated production cycle. J. Geophys. Res. Oceans 104: 3341-3356. doi:10.1029/1998JC900004

Raven, J. A., A. M. Johnston, J. E. Kübler, and others. 2002. Mechanistic interpretation of carbon isotope discrimination by marine macroalgae and seagrasses. Funct. Plant Biol. 29: 355-378.

Rodellas, V., J. Garcia-Orellana, P. Masqué, M. Feldman, and Y. Weinstein. 2015. Submarine groundwater discharge as a major source of nutrients to the Mediterranean Sea. Proc. Natl. Acad. Sci. 112: 3926-3930. doi:10.1073/pnas.1419049112

Rodellas, V., J. Garcia-Orellana, A. Tovar-Sánchez, G. Basterretxea, J. M. LópezGarcia, D. Sánchez-Quiles, E. Garcia-Solsona, and P. Masqué. 2014. Submarine groundwater discharge as a source of nutrients and trace metals in a Mediterranean bay (Palma Beach, Balearic Islands). Mar. Chem. 160: 56-66. doi:10.1016/j.marchem.2014.01.007

Rodellas, V., T. C. Stieglitz, A. Andrisoa, P. G. Cook, P. Raimbault, J. J. Tamborski, P. van Beek, and 0. Radakovitch. 2018. Groundwater-driven nutrient inputs to coastal lagoons: The relevance of lagoon water recirculation as a conveyor of dissolved nutrients. Sci. Total Environ. 642: 764-780. doi:10.1016/j.scitotenv.2018.06.095

Ruiz, M., and J. Velasco. 2009. Nutrient Bioaccumulation in Phragmites australis: Management Tool for Reduction of Pollution in the Mar Menor. Water. Air. Soil Pollut. 205: 173. doi:10.1007/s11270-0090064-2

Sadat-Noori, M., I. R. Santos, D. R. Tait, and D. T. Maher. 2016. Fresh meteoric versus recirculated saline groundwater nutrient inputs into a subtropical estuary. Sci. Total Environ. 566-567: 1440-1453. doi:10.1016/j.scitotenv.2016.06.008

Santiago, L. S., K. Silvera, J. L. Andrade, and T. E. Dawson. 2017. Functional strategies of tropical dry forest plants in relation to growth form and 
isotopic composition. Environ. Res. Lett. 12: 115006. doi:10.1088/1748-9326/aa8959

Santos, I. R., K. R. Bryan, C. A. Pilditch, and D. R. Tait. 2014. Influence of porewater exchange on nutrient dynamics in two New Zealand estuarine intertidal flats. Mar. Chem. 167: 57-70. doi:10.1016/j.marchem.2014.04.006

Santos, I. R., B. D. Eyre, and M. Huettel. 2012a. The driving forces of porewater and groundwater flow in permeable coastal sediments: A review. Estuar. Coast. Shelf Sci. 98: 1-15. doi:10.1016/j.ecss.2011.10.024

Santos, I. R., D. T. Maher, and B. D. Eyre. 2012b. Coupling Automated Radon and Carbon Dioxide Measurements in Coastal Waters. Environ. Sci. Technol. 46: 7685-7691. doi:10.1021/es301961b

Santos Isaac R., Cook Perran L. M., Rogers Louissa, Weys Jason de, and Eyre Bradley D. 2012. The "salt wedge pump" : Convection - driven pore - water exchange as a source of dissolved organic and inorganic carbon and nitrogen to an estuary. Limnol. Oceanogr. 57: 1415-1426. doi:10.4319/lo.2012.57.5.1415

Sigman, D. M., M. A. Altabet, R. Michener, D. C. McCorkle, B. Fry, and R. M. Holmes. 1997. Natural abundance-level measurement of the nitrogen isotopic composition of oceanic nitrate: an adaptation of the ammonia diffusion method. Mar. Chem. 57: 227-242.

Siokou-Frangou, I., U. Christaki, M. G. Mazzocchi, M. Montresor, M. Ribera d'Alcalá, D. Vaqué, and A. Zingone. 2010. Plankton in the open Mediterranean Sea: a review. Biogeosciences 7: 1543-1586. doi:https://doi.org/10.5194/bg-7-1543-2010

Slomp, C. P., and P. Van Cappellen. 2004. Nutrient inputs to the coastal ocean through submarine groundwater discharge: controls and potential impact. J. Hydrol. 295: 64-86. doi:10.1016/j.jhydrol.2004.02.018

Stieglitz, T. C., P. van Beek, M. Souhaut, and P. G. Cook. 2013. Karstic groundwater discharge and seawater recirculation through sediments in shallow coastal Mediterranean lagoons, determined from water, salt and radon budgets. Mar. Chem. 156: 73-84. doi:10.1016/j.marchem.2013.05.005

Street, J. H., K. L. Knee, E. E. Grossman, and A. Paytan. 2008. Submarine groundwater discharge and nutrient addition to the coastal zone and coral reefs of leeward Hawai'i. Mar. Chem. 109: 355-376. doi:10.1016/j.marchem.2007.08.009

Syrett, P. J. 1981. Nitrogen metabolism of microalgae. Can. Bull. Fish. Aquat. Sci. Taniguchi, M., T. Ishitobi, and J. Shimada. 2006. Dynamics of submarine groundwater discharge and freshwater-seawater interface. J. Geophys. Res. Oceans 111. doi:10.1029/2005JC002924

Tovar-Sánchez, A., G. Basterretxea, V. Rodellas, and others. 2014. Contribution of Groundwater Discharge to the Coastal Dissolved Nutrients and Trace 
Metal Concentrations in Majorca Island: Karstic vs Detrital Systems. Environ. Sci. Technol. 48: 11819-11827. doi:10.1021/es502958t

Tseng, L. Y., A. K. Robinson, X. Zhang, and others. 2016. Identification of Preferential Paths of Fossil Carbon within Water Resource Recovery Facilities via Radiocarbon Analysis. Environ. Sci. Technol. 50: 1216612178. doi:10.1021/acs.est.6b02731

Valiela, I., and J. E. Costa. 1988. Eutrophication of Buttermilk Bay, a Cape Cod coastal embayment: concentrations of nutrients and watershed nutrient budgets. Environ. Manage. 12: 539-553.

Valiela, I., K. Foreman, M. LaMontagne, and others. 1992. Couplings of watersheds and coastal waters: sources and consequences of nutrient enrichment in Waquoit Bay, Massachusetts. Estuaries 15: 443-457.

Vizzini, S., and A. Mazzola. 2003. Seasonal variations in the stable carbon and nitrogen isotope ratios (13C/12C and $15 \mathrm{~N} / 14 \mathrm{~N})$ of primary producers and consumers in a western Mediterranean coastal lagoon. Mar. Biol. 142: 1009-1018. doi:10.1007/s00227-003-1027-6

Vizzini, S., B. Savona, M. Caruso, A. Savona, and A. Mazzola. 2005. Analysis of stable carbon and nitrogen isotopes as a tool for assessing the environmental impact of aquaculture: a case study from the western Mediterranean. Aquac. Int. 13: 157-165. doi:10.1007/s10499-0049023-5

Wang, H., M. Dai, J. Liu, and others. 2016. Eutrophication-Driven Hypoxia in the East China Sea off the Changjiang Estuary. Environ. Sci. Technol. 50: 2255-2263. doi:10.1021/acs.est.5b06211

Weinstein, Y., Y. Yechieli, Y. Shalem, W. C. Burnett, P. W. Swarzenski, and B. Herut. 2011. What Is the Role of Fresh Groundwater and Recirculated Seawater in Conveying Nutrients to the Coastal Ocean? Environ. Sci. Technol. 45: 5195-5200. doi:10.1021/es104394r

Welsh, D. T. 2000. Nitrogen fixation in seagrass meadows: regulation, plantbacteria interactions and significance to primary productivity. Ecol. Lett. 3: 58-71.

Yang, T., S.-Y. Jiang, J.-H. Yang, G. Lu, N.-Y. Wu, J. Liu, and D.-H. Chen. 2008. Dissolved inorganic carbon (DIC) and its carbon isotopic composition in sediment pore waters from the Shenhu area, northern South China Sea. J. Oceanogr. 64: 303-310. doi:10.1007/s10872-008-0024-2

Zhao, Y., X. Xia, and Z. Yang. 2013. Growth and nutrient accumulation of Phragmites australis in relation to water level variation and nutrient loadings in a shallow lake. J. Environ. Sci. 25: 16-25. doi:10.1016/S1001-0742(12)60004-7

Zheng, Z.-L. 2009. Carbon and nitrogen nutrient balance signaling in plants. Plant Signal. Behav. 4: 584-591. doi:10.4161/psb.4.7.8540

Zieman, J. C., S. A. Macko, and A. L. Mills. 1984. Role of Seagrasses and Mangroves in Estuarine Food Webs: Temporal and Spatial Changes in 
Stable Isotope Composition and Amino Acid Content During Decomposition. Bull. Mar. Sci. 35: 380-392. 